\title{
DSpace@MIT
}

\author{
MIT Open Access Articles
}

\section{Nuanced Accountability: Voter Responses to Service Delivery in Southern Africa}

The MIT Faculty has made this article openly available. Please share how this access benefits you. Your story matters.

Citation: De Kadt, Daniel, and Evan S. Lieberman. “Nuanced Accountability: Voter Responses to Service Delivery in Southern Africa." British Journal of Political Science (December 13, 2017): 131.

As Published: http://dx.doi.org/10.1017/S0007123417000345

Publisher: Cambridge University Press (CUP)

Persistent URL: http://hdl.handle.net/1721.1/118646

Version: Author's final manuscript: final author's manuscript post peer review, without publisher's formatting or copy editing

Terms of use: Creative Commons Attribution-Noncommercial-Share Alike 


\title{
Nuanced Accountability:
}

\section{Voter Responses to Service Delivery in Southern Africa}

\author{
Daniel de Kadt* Evan S. Lieberman ${ }^{\dagger}$
}

Online appendix available here.

\begin{abstract}
Various theories of democratic governance posit that citizens should vote for incumbent politicians when they provide good service, and vote for the opposition when service delivery is poor. But does electoral accountability work as theorized, especially in developing country contexts? Studying Southern African democracies, where infrastructural investment in basic services has expanded widely but not universally, we contribute a new empirical answer to this question. Analyzing the relationship between service provision and voting, we find a surprising negative relationship: improvements in service provision predict decreases in support for dominant party incumbents. Though stronger in areas where opposition parties control local government, the negative relationship persists even in those areas where local government is run by the nationally dominant party. Survey data provides suggestive evidence that citizen concerns about corruption and ratcheting preferences for service delivery may be driving citizen attitudes and behaviors. Voters may thus be responsive to service delivery, but perhaps in ways that are more nuanced than extant theories previously recognized.
\end{abstract}

Keywords: Democracy, accountability, elections, voting, attitudes, service provision, Southern Africa

${ }^{*}$ Ph.D. Candidate, Department of Political Science, Massachusetts Institute of Technology. Email: ddekadt@mit.edu

TProfessor and Total Chair on Contemporary Africa, Department of Political Science, Massachusetts Institute of Technology. Email: evanlieb@mit.edu 


\section{INTRODUCTION}

Electoral accountability - the notion that citizens use the vote to influence government action is a central tenet of democratic theory (Downs 1957, Fearon 1999). It continues to inform active scholarly and policy debates about the quality of government, including how to devise policies to improve the well-being of poor people in poor countries (Przeworski et al. 2000, Gerring, Thacker and Alfaro 2011. But does democracy work as theorized? Do citizens actually use their vote to hold politicians accountable for delivering, or failing to deliver, much needed goods and services? Despite the centrality of this question, surprisingly little high-quality empirical evidence has been brought to bear on it, particularly in developing country contexts. In this paper we contribute a new (and surprising) empirical answer, and explore mechanisms that account for our findings.

We test the accountability hypothesis in its purest form: do dramatic improvements in key service areas, those with direct implications for public health (water provision, sewerage, and refuse collection), lead to increased electoral returns to the incumbent? We consider four Southern African democracies, and present two primary sets of empirical tests of whether accountability works as commonly assumed. First, we exploit extensive variation in the degree of change in service delivery coverage between 2001 and 2011 in South Africa, the largest democracy in Southern Africa. Combining data from the 1999 and 2009 national elections, 2000 and 2011 local elections, and the 2001 and 2011 censuses, we study how variation in the change of service provision across these three different services relates to changes in voting for the incumbent party (the African National Congress).

Strikingly, these analyses show that changes in access to services are negatively associated with changes in support for the incumbent. We then analyze Afrobarometer data, spatially linked to the census and electoral data, to probe whether this result also holds for individual voters. The key findings replicate at the micro-level in South Africa, but also in Botswana, Lesotho, and Namibia; controlling for a host of covariates and potential confounders, access to services systematically 
predicts lower support for the incumbent. These findings are not simply artifacts of the data, which predict numerous other relationships precisely as would be expected. Of course, because our study is based on observational data there are good reasons to be concerned about potentially spurious relationships and omitted variable bias, including from those factors that might determine where new services are provided. We attempt to address a range of such concerns, and these analyses leave us cautiously confident about our findings.

Crucially, our results cannot be simply explained away by differences in local partisan control. We do find, perhaps less surprisingly, that citizens in opposition-controlled municipalities are much less likely to vote for the national party in power the more services are expanded, even though the national party in power can credibly claim some credit for such services. Yet even in those cases where the dominant party is in control locally (and these are the vast majority of cases), both our aggregate data and survey data show that service delivery is negatively associated, at statistically significant levels, with incumbent voting. These findings cut against conventional expectations, and demand further exploration. In turn, we explore a number of theoretically and contextually motivated mechanisms, and find some evidence in favor of at least two.

First, increases in service delivery appear to heighten citizens' awareness of, and exposure to, corruption. Corruption is a salient political issue in most developing democracies, and so increased exposure to corruption may induce shifts in voting behavior. Second, we find that increases in service delivery appear to change voter expectations, ratcheting them upward. Once voters are provided with basic services, they may revise their expectations of government provision upward, seeking out alternative parties. Finally, we find mixed evidence that our results may be driven by relative deprivation, wherein voters care less about what they have in absolute terms, and more about what they have relative to others. In sum, we interpret these findings as evidence that voters engage in "nuanced accountability" - they pay attention to service delivery, but use their knowledge and experiences in ways that may be more nuanced than have previously been considered. 
Our study has important implications for a number of literatures in political science and development. First and foremost, we contribute a new empirical answer to the question of whether electoral accountability works as is often assumed. The answer is surprising - improved service provision is not associated with increasing incumbent vote share in any of the four cases examined. We find that voters are instead quite nuanced in their assessments of and reactions to government performance. Second, our findings speak to broader questions about the relationship between democracy and development (i.e. Ross 2006), in which there has not been a consistently pro-poor bias, at least relative to non-democracies. Finally, our findings suggest that policy researchers interested in establishing positive feedback loops between voters and politicians should be cautious about the workings of straightforward accountability.

\section{Theoretical Expectations for Voter Behavior under Electoral ACCOUNTABILITY}

How do citizens behave in their capacity as principals in developing democracies? We study a simple but largely untested assumption underlying democratic theory: that citizens will be straightforwardly more likely to reward incumbent politicians with their votes when politicians actually deliver services.

Testing this assumption is critical for shedding light on generations of scholarship investigating the material consequences of democratic government (i.e., Lipset 1959, Przeworski et al. 2000. Recent empirical work on the determinants of service delivery has focused largely on comparisons between democracies and non-democracies Brown 1999, Stasavage 2005a ba Lake and Baum 2001. Haggard and Kaufman 2008, Ross 2006) 1. While illuminating, such studies necessarily must put a "black box" around the specific machinations of democratic government, and largely do not parse out the role of citizens and politicians. By contrast, our goal is to better understand how democracies work in practice, with a specific focus on the role of citizens in elections.

\footnotetext{
${ }^{1}$ For a comprehensive review of this literature, see Golden and Min 2013.
} 
The concept of "electoral accountability" is rooted in the twin expectations that politicians are concerned about how citizens will vote, and that citizens will use their votes to punish (reward) politicians for bad (good) performance Svolik 2013, 685-6). While the first expectation - that politicians seek re-election so long as it benefits them - is relatively uncontroversial and easy to observe, the second demands more careful examination. Underpinning this expectation is an assumption about how citizens will behave if they observe government providing the very good that they say they desire. In particular, within societies in which basic services (such as piped water, sanitation, and refuse collection) are demanded but not universally provided, can we safely assume that citizens will be more likely to vote for the government that provides them?

While such expectations are intuitively plausible, absent strong and conclusive evidence that democracies are outperforming the alternatives in terms of providing basic services to citizens, scholars have sought to better understand where democratic theory might break down in practice. Indeed, in recent years, much research on democratic governance in developing country contexts has focused on the structural and institutional constraints on citizens' abilities to act as effective principals. A prominent explanation from this literature is that "informational asymmetries" are to blame. That is, the lack of availability of quality information about government performance amongst poor voters in poor countries can explain the sometimes surprising voting behavior Besley and Burgess 2001; World Bank 2003. As a result, a number of recent interventions have sought to increase the quality of accountability through deliberate information campaigns, though with decidedly mixed results Bruns, Filmer and Patrinos 2011, Pande 2011, Lieberman, Posner and Tsai 2014). Relatedly, Gottlieb (2015) highlights that an additional problem may be that voters lack context concerning what to expect from politicians, and finds that by providing information about standards and expectations, citizens are more likely to sanction poor performers.

Notwithstanding the important findings from these sets of studies, a central question still remains: Absent informational and structural barriers of the types described above, do citizens behave as democratic theory predicts? That is, are they more likely to vote for incumbents when they 
receive services? The closest study to the research we endeavor here is a recent analysis of the relationship between road provision and voting in contemporary Ghana Harding 2015), in which the author finds that an improvement in road quality leads to an increase in the incumbent party's vote share. While Harding s 2015 contribution is significant, his study considers one form of government service, in one country. Further, given the substantial positive externalities associated with road access, it is not clear whether the effect is generated through satisfaction with roads per se, or with economic returns caused by road infrastructure. It is important to consider this relationship in a range of other contexts, and we attempt to build on Harding s 2015 findings and insights, particularly by focusing on visible and attributable goods. Specifically, Harding and Stasavage 2013, in a discussion of how governments are responsive to voters, follow Mani and Mukand 2007, who argue that governments are more likely to shift resources to outcomes that are less "noisy" or more "attributable" to government. Harding (2015) makes a similar argument about voters' assessments of public goods, and finds that Ghanaian voters hold politicians accountable for road investment (a visible and attributable good), but not for education quality (more noisy and less attributable). Relatedly, scholars have raised concerns about the likelihood of electoral accountability when citizens are unsure about who to credit or to blame for services under conditions of divided governments or diverse coalitions..$^{2}$

Thus, the weight of theoretical expectations about voter behavior in the context of incomplete infrastructural service delivery are relatively straightforward: When new services are provided, attributable, and visible, and the party in power is also easy to observe, all else equal, voters should be more likely to perceive their own lives as having improved, to credit the government for such improvements, and most importantly, to favor the incumbent in the electoral arena. Such expectations motivate the research described in subsequent sections, but as we demonstrate, some of our findings point in exactly the opposite direction. After describing our research design and results, we return to our theoretical discussion, and we advance and test additional hypotheses concerning the explanation for those results. We note that do not present the latter theoretical

\footnotetext{
${ }^{2}$ See Ashworth $(2012$ for review on electoral accountability.
} 
discussion here because we seek to be transparent about the order of inquiry in our research - we wish to make clear that we theorized about the negative relationship between increased service delivery and change in incumbent vote share only after those first order results were apparent to us.

\section{Research Design, Study Context, and Data}

Our research design combines analyses of fine-grained local-level data within one country (South Africa) with a range of analyses of individual-level data in four Southern African democracies. At the aggregate level, we first exploit variation in the provision of services within political units over time. Within a first-differences design, we estimate the average association between the change in service delivery (our explanatory variable, for various services) and the change in incumbent voteshare (our dependent variable), within political units over time. Our unit is the political "ward", specifically the 2011 ward boundaries $3^{3}$ The first-differences design absorbs time-invariant or slowmoving confounders, but we also control for the change in a range of important demographic and socio-economic covariates. To further strengthen our analyses we include a number of baseline level covariates. As such, our design rules out a large swathe of potential confounders, isolating the effect of change in service delivery when voting behavior in units follow similar (parallel) trends over time.

\footnotetext{
${ }^{3}$ South African governance is federal in conception, but substantially centralized in practice. The country is divided into 9 provinces, each with its own elected parliament and government, but with limited fiscal independence from the central state. Below these 9 provinces sit 52 districts, and below them 234 municipalities (numbers valid at the time of writing, as districts, municipalities, and wards are adjusted through a demarcation process every five years). These municipalities are the primary locus of local government, and come in two different forms. Eight metropolitan municipalities administer the eight major cities in South Africa, while 226 local municipalities administer the rest of the country, including smaller cities, towns, peri-urban, and rural areas. The municipalities are further decomposed into geographically defined "wards," of which there are currently 4277. Each ward serves as a single-member district, in which voters elect councillors to represent them in the municipal council. Ward candidates almost always run as the representative of a party, and parties may replace elected councillors with other individuals during their term, reinforcing the overall power of parties.
} 
We complement this aggregate-level analysis with regression and matching analyses at the individuallevel using data from several rounds of the Afrobarometer, spatially linked to the aggregate-level data. We replicate our individual-level results in Botswana, Namibia, and Lesotho, three of South Africa's neighbors. Together, our analyses paint a fairly consistent relationship concerning the association between service access (at the individual-level, and various levels of aggregation) and attitudes towards government and votes for the incumbent.

\subsection{SOUth AFriCAN POLITICS AND SERVICE DELIVERY}

We focus primarily on the case of post-Apartheid South Africa. This case is well suited to answering our primary question because we are able to observe, using high quality high resolution data, wide variation in patterns of change in visible and attributable service delivery (water, sewerage, and refuse collection) 4 During the fall of Apartheid, the African National Congress (ANC), then led by Nelson Mandela, campaigned on the provision of basic services to the newly enfranchised Black majority with the slogan "a better life for all." South Africans came to expect drastically improved service delivery, and the issue has remained salient throughout the post-Apartheid era. Since the first multi-racial, democratic election in 1994, the state has vastly expanded basic infrastructure and services across the country while still falling far short of universal delivery. The fact that the ANC has controlled national government since 1994 leaves little ambiguity about responsibility for new service provision. Notwithstanding, South Africa's is still a competitive electoral system, and there is variation in who voters choose to support. In particular, there is political heterogeneity at the local level, where roughly one-quarter of municipalities have been controlled by an opposition party. Beyond South Africa, Botswana, Lesotho, and Namibia are similarly well suited for testing electoral accountability.

\footnotetext{
${ }^{4}$ Two other studies (World Bank. 2011 and Booysen 2007) have raised the question of democratic accountability in the specific context of post-Apartheid South Africa that we consider here. However, in neither case do the authors systematically investigate the relationship between service delivery and voting behavior. See also, Kroth, Larcinese and Wehner 2015), which investigates the relationship between Black enfranchisement and mass electrification.
} 
We assume that preferences for basic services are universal, but these preferences and their salience can be demonstrated empirically. In general, in the fifth round of the Afrobarometer, service delivery was the third most cited problem after unemployment and housing for South Africans. Service delivery is also ubiquitous in political discourse. Protests focusing specifically on the quality of service delivery occur regularly throughout the country, and politicians have repeatedly campaigned on service delivery issues.

At the individual level, we further focus our analyses on Black South Africans, who constitute the overwhelming majority (approximately 80 percent) of the population. This group was most severely excluded from citizenship and service provision during Apartheid 5 Other race groups in South Africa - notably Coloureds and Asians/Indians - also lacked access to basic services to a degree in the early 1990s, but their small numbers and geographic concentration make them less suitable for the types of analyses we undertake here.

Our work builds on prior studies that have investigated South African voting behavior during the apartheid era. In line with Ferree 2006), we recognize strong differences in voter preferences by race group, but also investigate within-group patterns, looking for clues of performance-based evaluations.

While South African elections have been labelled a "racial census," there is a strong suggestion in prior research that voters in South Africa do appear to care about party positions and government achievements Mattes 1995, Mattes and Piombo 2001, Bratton and Mattes 2003. Similarly, outside of the South African case, researchers in sub-Saharan Africa find that economic concerns can be crucial in voting decisions (Posner and Simon 2002, Weghorst and Lindberg 2013). It is worth noting, however, that prior studies of South African voting behavior have analyzed survey data from an earlier era of the post-Apartheid history, when normative attitudes towards the

${ }^{5}$ The Apartheid state classified four racial groups: Black African, Coloureds, Indians, and Whites. These categories are still used by the South African government, and remain salient to this day. 
ruling ANC party were much more likely to be favorable among the black population owing to the organization's pivotal role in national transformation. We further contribute to this rich literature by studying objective measures of government performance, rather than perceptions thereof - in later sections we discuss the correspondence between actual government performance and stated perceptions.

It appears to us that voters in South Africa likely care about service provision and government performance. This service provision is a responsibility shared by a range of government structures at different levels, in part determined by the service of interest. Services like education and policing are typically administered more nationally, along with electrification (due to dependence on the national grid). All three services we study in this paper - water, sanitation, and refuse are primarily administered at the local level. Access and quality are largely determined by the particular municipal council, who serve as the front-end "retailer" 6

Moreover, while we consider a range of government services, we do not analyze two substantively important services, electrification and education. Electrification has documented knock-on economic effects in local communities Dinkelman 2011, which renders testing electoral accountability difficult (we may instead be picking up the association between economic development and voting). Electricity theft also occurs throughout South Africa, making it hard to back out from census self-reports whether households actually have government provided access. It is quite plausible that any measurement error induced by theft would act as a confounder, making inferences hard to draw. More than any other service in South Africa, electricity provision is constrained

\footnotetext{
${ }^{6}$ Chapter 7 of the South African Constitution declares that one object of municipalities is "to ensure the provision of services to communities in a sustainable manner" (sec 152(1).b). The Constitution also stipulates that municipalities must have a developmental focus: they should "give priority to the basic needs of the community" (sec 153.a). Water services, such as the provision of clean running water to households, and sewerage (hooking up homes to pipes and the provision of sanitary public toilets), as well as refuse collection and disposal are the responsibility of the local government. Moreover, basic levels of these services are provided free of charge to all South Africans. Citizens are liable for their consumption of electricity and water if they consume beyond a "basic" allocation.
} 
by both stock and flow delivery. $]^{7}$ Finally, the expansion of electrification services has been so extensive - in 2011, 85.1 percent of South African households used electricity as their primary source of lighting - that we have less variation to explore. None of the above problems affect water, sanitation, or refuse collection in a similar way.

We also do not study education, despite it being a major budget priority for the South African government. Education is a much less attributable good, because it is hard for voters to monitor the performance of local teachers and schools Harding 2015. Moreover, on the metric collected through the national census - percent of children enrolled in school - there has been very little change over-time. Again, these problems do not affect the services we study.

\subsection{THE LOGIC OF SERVICE PROVISION}

Our research design requires that changes in service delivery over time are independent of timevarying confounding variables. While the first-differences design is advantageous, because services are not randomly assigned we should remain cautious. The primary challenge to our approach is that service provision may be politicized and targeted strategically. If this were the case, the trends in political behavior in areas with high changes in service delivery may be very different from low change areas, generating spurious results. Fortunately, available evidence suggests that this is not a major concern.

Service provision in South Africa is governed by the principles of the Batho Pele initiative, launched in 1997 by Mandela's government, which created relatively transparent formula-based allocations for local financial support. Despite the uniformity of goals, there remains heterogeneity in the roll out of services to those in need. As most implementation of service delivery is administered by municipal governments, the quality and reach of services is often defined by the capacity

${ }^{7}$ The South African government has done an excellent job of expanding the grid to include previously excluded areas, but has failed to increase capacity correspondingly. The result is that the country has been plagued with rolling blackouts ("load shedding") since 2007. How should voters react to increased hookups if electricity flow is highly unpredictable? 
of the municipal governments themselves. While parties are able to "deploy" politicians, technocrats, and bureaucrats to some areas, the vast majority of municipal workers are sourced from local communities. The primary input for service delivery is, however, financial disbursements. These are national government allocations from the treasury, which determine the fiscal resources available to particular local governments, with some funds earmarked for particular portfolios.

There are two central components to disbursements from the national treasury. The first, which represents the bulk of transfers, are known as the "Local Government Equitable Share," and defined by formula. The formula, reviewed every few years by a committee, typically up-weights the transfers to municipalities with higher numbers of poor households (hence "equitable"). The second are known as "Local Government Conditional Allocations," which comprise smaller transfers of task or project specific funds to municipal governments. These conditional transfers are often highlighted as particularly "political", given that there is more discretion and less transparency in determining their recipients. Typically, however, the conditional component is dwarfed by the equitable share component, suggesting that the national government has limited discretion in this regard.

There is very little reliable research into whether the disbursements from national government are politically motivated. The most sophisticated analysis of political bias in treasury disbursements is Kroth 2014, who analyzes the disbursements to the provinces (not the municipalities). Kroth finds that there is some distortion in the (provincial) equitable share specifically around election years - the ANC seemingly directs more funding to less competitive places. This fact which makes our negative findings all the more remarkable; if the ANC is engaged in any financial targeting, it appears to be targeting the places where it is doing best, rather than places that are trending toward the opposition.

One suggestive test of whether service delivery is targeted strategically, is whether baseline ANC vote share is a good predictor of changes over time. To test this, we regressed ward-level changes in service delivery (2001 to 2011) on a range of baseline covariates (those we also control for in our 
Table 1: Does baseline ANC vote share predict service delivery changes?

\section{Dependent Variable:}

\begin{tabular}{|c|c|c|c|c|c|c|c|c|}
\hline \multirow{3}{*}{ anc_vs1999 } & \multicolumn{2}{|c|}{$\Delta$ Water } & \multicolumn{2}{|c|}{$\Delta$ Toilets } & \multicolumn{2}{|c|}{$\Delta$ Refuse } & \multicolumn{2}{|c|}{$\Delta$ Mean ServD } \\
\hline & \multicolumn{8}{|c|}{ Panel A: Full Sample (and <80th Percentile Baseline ServD) } \\
\hline & $\begin{array}{c}0.019 * \\
(0.012)\end{array}$ & & $\begin{array}{c}-0.004 \\
(0.019)\end{array}$ & & $\begin{array}{l}0.046^{* *} \\
(0.020)\end{array}$ & & $\begin{array}{c}0.020^{*} \\
(0.012)\end{array}$ & \\
\hline anc_vs2000 & & $\begin{array}{c}0.015 \\
(0.013)\end{array}$ & & $\begin{array}{l}-0.011 \\
(0.020)\end{array}$ & & $\begin{array}{c}0.032 \\
(0.020)\end{array}$ & & $\begin{array}{c}0.012 \\
(0.012)\end{array}$ \\
\hline Constant & $\begin{array}{c}-0.214^{*} \\
(0.110)\end{array}$ & $\begin{array}{c}-0.187^{*} \\
(0.111)\end{array}$ & $\begin{array}{l}0.437^{* *} \\
(0.176)\end{array}$ & $\begin{array}{l}0.452^{* *} \\
(0.177)\end{array}$ & $\begin{array}{l}0.470^{* *} \\
(0.189) \\
\end{array}$ & $\begin{array}{c}0.512^{* * *} \\
(0.191)\end{array}$ & $\begin{array}{c}0.231^{*} \\
(0.123)\end{array}$ & $\begin{array}{l}0.259^{* *} \\
(0.124)\end{array}$ \\
\hline Covariates & $\mathrm{Y}$ & $\mathrm{Y}$ & $\mathrm{Y}$ & $\mathrm{Y}$ & $\mathrm{Y}$ & $\mathrm{Y}$ & $\mathrm{Y}$ & $\mathrm{Y}$ \\
\hline $\mathrm{N}$ & 2909 & 2886 & 2909 & 2886 & 2909 & 2886 & 2909 & 2886 \\
\hline \multirow[t]{2}{*}{ R-squared } & 0.184 & 0.184 & 0.112 & 0.114 & 0.065 & 0.064 & 0.162 & 0.161 \\
\hline & \multicolumn{8}{|c|}{$\underline{\text { Panel B: Competitive Wards Only (and <80th Percentile Baseline ServD) }}$} \\
\hline anc_vs1999 & $\begin{array}{l}-0.002 \\
(0.017)\end{array}$ & & $\begin{array}{c}0.008 \\
(0.030)\end{array}$ & & $\begin{array}{c}0.053 \\
(0.035)\end{array}$ & & $\begin{array}{c}0.020 \\
(0.019)\end{array}$ & \\
\hline anc_vs2000 & & $\begin{array}{c}0.005 \\
(0.020)\end{array}$ & & $\begin{array}{c}0.005 \\
(0.027)\end{array}$ & & $\begin{array}{c}0.046^{*} \\
(0.027)\end{array}$ & & $\begin{array}{c}0.019 \\
(0.018)\end{array}$ \\
\hline Constant & $\begin{array}{c}-0.335^{* * *} \\
(0.121)\end{array}$ & $\begin{array}{c}-0.250^{*} \\
(0.150)\end{array}$ & $\begin{array}{c}0.188 \\
(0.307)\end{array}$ & $\begin{array}{c}0.181 \\
(0.251)\end{array}$ & $\begin{array}{c}0.468 \\
(0.342)\end{array}$ & $\begin{array}{c}0.512^{*} \\
(0.308)\end{array}$ & $\begin{array}{c}0.107 \\
(0.207)\end{array}$ & $\begin{array}{c}0.148 \\
(0.182) \\
\end{array}$ \\
\hline Covariates & $\mathrm{Y}$ & $\mathrm{Y}$ & $\mathrm{Y}$ & $\mathrm{Y}$ & $\mathrm{Y}$ & $\mathrm{Y}$ & $\mathrm{Y}$ & $\mathrm{Y}$ \\
\hline $\mathrm{N}$ & 861 & 961 & 861 & 961 & 861 & 961 & 861 & 961 \\
\hline R-squared & 0.195 & 0.192 & 0.119 & 0.135 & 0.035 & 0.043 & 0.136 & 0.151 \\
\hline
\end{tabular}

${ }^{* * *} \mathrm{p}<.01 ;{ }^{* *} \mathrm{p}<.05 ;{ }^{*} \mathrm{p}<.1$

Standard errors clustered by municipality (234) 
main specifications) and ANC vote share in 1999 (national) and 2000 (local). We conduct this test for two samples, which we use for the analyses throughout the paper. First, in Panel A of table 11 we show results for the full sample, though note that throughout the paper we drop all wards in which baseline service coverage (for all three relevant service) is above the 80th percentile, to prevent ceiling effects. Second, in Panel B of table 1 we include only competitive wards - those in which baseline ANC vote share was between $30 \%$ and $70 \%$. Together, the results of this exercise show zero or close-to zero estimates in about 12 out of 16 tests, and four which are statistically significant, though three only at the 10 percent significance level.

Together with the evidence presented by Kroth 2014, this empirical exercise suggests that the ANC has limited discretion to influence the geographic distribution of local service delivery, and when it does, it does so in ways that likely could not account for our negative findings.8

\subsection{DATA}

Our first analyses use aggregated voting data drawn from polling-place election returns from the 1999 and 2009 national, and the 2000 and 2011 local elections.9 We combine these with aggregate data from the South African censuses of 2001 and 2011, which enumerated household access to water, flush toilets, and regular refuse collection, as well as a range of social and demographic factors of interest. We aggregate the data to the 2011 ward level $(n=4277)$. While the ANC

${ }^{8}$ Finally, note that a body of research studying distributive politics in Sub-Saharan Africa finds that, when targeting occurs, it is usually to groups that are allied to those in power, not to opposition groups. As such, if the ANC is targeting service delivery strategically, it would mostly likely be doing so in such a way as to reward strong and probably stable pro-ANC voters, not target areas that are gradually becoming less ANC.

${ }^{9}$ Since 1994, there has been a National and Provincial Election every 5 years $(1994,1999,2004$, 2009, 2014), electing South Africa's national parliament, its provincial parliaments, and its second chamber, the national council of provinces. The electoral system is pure proportional representation, with two ballots, one for the national parliament and one for the provincial parliament. The president serves at the behest of a joint sitting of parliament. The first Local Government Elections were held in 1996, and have been held regularly since then (1996, 2000, 2006, 2011). In these elections, which follow a mixed system, voters choose politicians (councillors) and parties that will represent them in their municipal councils. 
has remained hegemonic in South African politics, there is substantial local-level variation in the ANC's electoral performance over time ${ }^{10}$

Wards are redistricted in South Africa every five years. We constructed our panel data using the 2011 political geography (the current geography at time of writing), and retro-actively fit older data to these new boundaries, using lower-level electoral and census units that fit into the 2011 boundaries.

South African census data is nested within enumeration areas (roughly 60,000 - 90,000 observations, depending on year). These data were released pre-aggregated to the 2011 ward and municipal levels by Statistics South Africa (Stats SA, the census bureau) 11 The election data were made available at the polling place level (roughly 15,000 to 22,000 observations, depending on year). The polling place polygons fit, in almost all cases, cleanly into the 2011 wards, so we aggregate from the polling place up to the 2011 ward and municipal levels. For ease of interpretation, all variables are rescaled to range from 0 to 1 .

Additionally, it is worth noting that not all changes in service provision are entirely attributable to direct government action: some services, especially those that reach inside the household (such as installing a flush toilet) are privately provided, and we do not have data that allow us to

\footnotetext{
${ }^{10}$ We show in the Appendix the distribution of over-time change in ANC electoral performance (at the ward level) in both the national and local elections. While the ANC has clearly maintained its hegemonic control of South African politics (both densities centre around zero), there is evidence of a high degree of ward-level change. Further, it should be noted that in the 2014 elections there were a number of "abstention" campaigns that led to many voters not voting. In coding our dependent variable, ANC vote share, we assign abstensions the same value as non-voters. That is, we do not count abstaining voters who may in fact support the ANC, nor abstaining voters who may be voicing their dislike of the party. Given that our election data are for the period 1999-2009 (prior to the abstention movements), and given the scale of abstentions, we are not particularly concerned about the implications of this for our results.

${ }^{11}$ This is done by converting the enumeration areas to centroid-points, and spatially joining them to ward and municipal polygons. We rely on Stats SA's aggregation of the census data for this study. We do have access to lower-level data for 2011, but the 2001 census was not made publicly available at the EA or Small-Area layer, which means we cannot reconstruct the data Stats SA releases for 2001.
} 
distinguish the share of government action. Nonetheless, we believe that our data still provide a strong basis for testing the core theories of democratic governance. First, if we make the reasonable assumption that the public/private mix of new service provision is relatively evenly distributed across space, we may make unbiased estimates of the effects of new services. Second, the services we consider almost always rely on a degree of government-provided infrastructure whether or not the final point of delivery is publicly-provided. Third, given the widespread discourse around government's failure to provide basic services, we assume that frustrations towards lack of services will be directed at the government, and it would not follow from conventional theory that those who managed to attain services on their own would systematically punish the government for this state of affairs. Finally, with respect to the South African case, we are not aware of any evidence of rival parties seeking to attract voters by targeting them with the private provision of local public goods in the manner Thachil 2014 finds in the case of India.

The set of key aggregate-level measures are presented in Table 2, including a "mean service delivery" measure that combines the three services of interest. Our final dataset is a two-wave panel, with $t_{1}$ in the early 2000s (1999-2001), and $t_{2}$ around 2010 (2009-2011). To these key variables we also add a number of economic and demographic covariates from the census data. This ensures that our results are not being driven by a number of plausible confounders, including unemployment levels, income levels, population size, gender proportions, the formality of dwellings, the proportion of whites in the area, and the share of each ward that falls within a traditional authority are. Several of these variables actually drive the formula-based budget allocations. 12

We complement our aggregate analyses with five rounds of the nationally-representative Afrobarometer survey data, which, when spatially linked to the data described above, allow us to

\footnotetext{
${ }^{12}$ One may note that our national election data, which is a change from 1999-2009, is measured before our census data, 2001-2011. This is unavoidable given the timing of elections and the release of data. However, we see the data as proxies of latent or underlying processes, rather than perfect measures. That is, as long as the change 1999-2009 is a good proxy for the latent change in ANC vote sentiment in the 2001-2011 period, we should not be concerned. Of course, this concern does not hold for our local election data, and the results across the two sets of elections are largely similar.
} 
Table 2: Key aggregate-level variables

\begin{tabular}{|c|c|c|c|c|c|c|}
\hline Variable & $t_{1}$ & $t_{2}$ & Source & Definition & Min & $\operatorname{Max}$ \\
\hline Water & 2001 & 2011 & Census & $\begin{array}{l}\text { The proportion of households } \\
\text { that have piped water into their } \\
\text { home }\end{array}$ & 0 & 1 \\
\hline Toilets & 2001 & 2011 & Census & $\begin{array}{l}\text { The proportion of households } \\
\text { that have fully or partially flush- } \\
\text { ing toilets }\end{array}$ & 0 & 1 \\
\hline Refuse & 2001 & 2011 & Census & $\begin{array}{l}\text { The proportion of households } \\
\text { that have refuse collected weekly }\end{array}$ & 0 & 1 \\
\hline Mean ServD & 2001 & 2011 & Census & $\begin{array}{l}\text { The mean of water, toilets, and } \\
\text { refuse coverage }\end{array}$ & 0 & 1 \\
\hline $\begin{array}{l}\text { Local ANC vote- } \\
\text { share }\end{array}$ & 2000 & 2011 & $\begin{array}{l}\text { Electoral } \\
\text { Commission }\end{array}$ & $\begin{array}{l}\text { The proportion of total votes in } \\
\text { area cast for ANC (local elec- } \\
\text { tions) }\end{array}$ & 0 & 1 \\
\hline $\begin{array}{l}\text { National ANC } \\
\text { voteshare }\end{array}$ & 1999 & 2009 & $\begin{array}{l}\text { Electoral } \\
\text { Commission }\end{array}$ & $\begin{array}{l}\text { The proportion of total votes in } \\
\text { area cast for ANC (national elec- } \\
\text { tions) }\end{array}$ & 0 & 1 \\
\hline
\end{tabular}

study whether census service coverage data is associated with individual-level attitudes and vote intentions. All but the first round of the Afrobarometer asked individuals about their household's access to at least one service, and so we are able to analyze whether self-reported access to services predicts voting intentions in similar ways to the aggregate data.

There is substantial variation in how service delivery has changed between 2001 to 2011. Figure 1 shows the relative distribution of these services in 2001 and 2011. Water delivery has improved most dramatically: The national coverage of households increased by 11.8 percentage points between 2001 and 2011, meaning that roughly 1.5 million more households were provided access to piped water in those ten years. Sewerage and refuse show more modest improvements, with increases of 7.2 and 4.7 percentage points, respectively, implying new access for at least 936,000 and 611,000 households ${ }^{13}$ Note that the graphs in figure 1 depict shifts in coverage percentage at the ward level - so even a small increase in the number of wards with $90 \%$ coverage may represent

\footnotetext{
${ }^{13}$ In fact, these numbers are almost certainly underestimates. Over the last ten years, South Africa's population has grown dramatically, and households have become smaller, implying that household growth has been high. As a result, it is probably the case that the reported numbers are low-end estimates of the new numbers of households covered.
} 
Figure 1: South African Basic Service Provision: 2001 and 2011 (Household Coverage Within Wards)
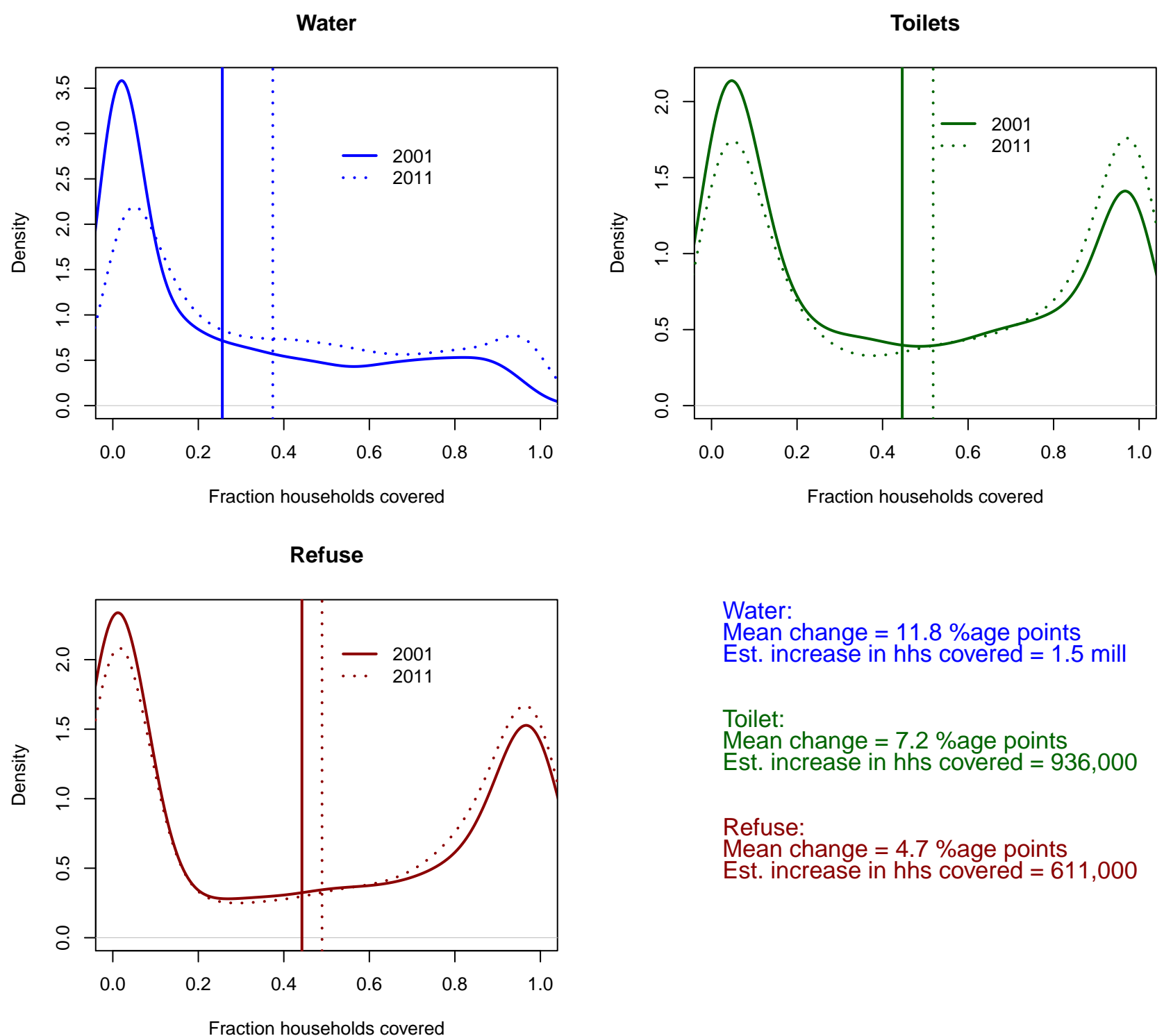

Water:

Mean change $=11.8 \%$ age points Est. increase in hhs covered $=1.5$ mill

Toilet:

Mean change $=7.2 \%$ age points

Est. increase in hhs covered $=936,000$

Refuse:

Mean change $=4.7 \%$ age points

Est. increase in hhs covered $=611,000$

Note: Each panel presents the distribution of service delivery coverage for households for a given service, at the ward level, in 2001 (solid line) and 2011 (dashed lines). The vertical lines are the year means (2001 is solid, 2011 dashed). The bottom right panel presents some key figures from the graphs. First, the percentage changes for each service. Second, the estimated number of new non-White households that have received services since 2001. This was estimated in a very simple fashion by taking the estimated number of households in South Africa $(\approx$ 13million - in 2001 there were roughly 12 million households in South Africa, and in 2011 roughly 15 million). This was then multiplied by the change in coverage. 
a dramatic increase in the number of people who have access to services. There is also considerable variation over geographic space, presented in a series of figures in the appendix. While service provision in South Africa has on the whole improved, there are a few areas in which it has worsened, notably in rural parts of the country.

\section{Analyses of Ward-Level Administrative and Voting Data}

Our aggregate-level analyses use a first-difference regression, specified as follows, for ward $i$, clustered by municipality $j$ :

$$
\Delta y_{i}=\alpha+\beta \Delta x_{i}+\delta \Delta w_{i}+\phi m_{i}+\eta_{j}
$$

Our outcome of interest is $\Delta y_{i}$, the change over two-periods in ANC vote share. $\alpha$ is the intercept, $\Delta x_{i}$ is the change in a particular service in question, while $\Delta w_{i}$ is a matrix of covariates (also differenced to capture change over time). $m_{i}$ are baseline covariates - including the baseline of the service in question - included to weaken the parallel trends assumption. $\eta_{j}$ is the error term, always estimated at the municipal (cluster) level. $\beta$ is the primary coefficient of interest, an estimate of the correspondence between changes in service provision and changes in ANC vote share.

With only two time periods, the first-differences specification simply regresses a single change on a single change, plus some error term, and time period fixed effects fall away.

To interpret the coefficient $\beta$ as causal, we must assume that $\Delta y_{i}$ and $\Delta x_{i}$ are not jointly determined by a time-varying confounder that has been omitted from the regression. By taking the first-difference of all the variables, the regression is robust to time-invariant confounders at the ward level. This is a superior test to conventional cross-sectional regressions in that a number of plausible confounders, such as non-varying or slow-moving geographic, economic, socio-cultural, or demographic features, are excluded. On top of this, we are also careful to include a number of 
time-varying covariates that could be driving our results, such as employment and income levels. We further include some baseline covariate levels in 2001, to essentially weaken the parallel trends assumption. In section 5.4 we also include a brief discussion of some potential confounding stories and the role of triangulated data and analyses.

\subsection{MAin RESUlts}

Our main results, estimated for changes in ANC vote share in national elections, are presented in table $3{ }^{14}$ The key results are to be found in the top four rows. We present two sets of results for each service using two samples (as in section 3.2). The first is the "full" sample, and includes all data less those observations in the top quintile of baseline service coverage. We exclude the top quintile of baseline service coverage to ensure that the results are not compromised by ceiling effects. In areas where baseline service coverage was already extremely high or almost universal, there was no possibility of substantive improvement. That is, if baseline service coverage is very high then changes are likely mechanically small, and if the ANC electoral performance is "trending" in some way we may recover a spurious relationship between the two driven by the ceiling effect. In the second sample, the "competitive sample," we also discard observations in which baseline ANC vote share fell outside of the window $30 \%-70 \%$. We do this because it is precisely in these competitive areas that we would expect electoral accountability to be most present, and to again ensure that ceiling effects are not driving our results.

Strikingly, we find that greater improvements in service provision typically predict declines in ANC electoral performance, systematically so at the national level, and for certain services at the local level. For those services (refuse and sewerage) that do not negatively predict changes in ANC electoral performance at the local level, we find quite precise zero estimates. The substantively

\footnotetext{
${ }^{14}$ Note that all the variables are scaled to range from 0 to 1 , so interpreting the coefficients and the marginal effects plots is straightforward. A change from 0 to 1 in the independent variable (service coverage) would result in a change in ANC vote share of magnitude $\hat{\beta}$ in the table, meaning that the magnitude of the coefficients can be directly compared.
} 
significant results are also broadly speaking statistically significant at conventional levels. In sum, the results show either negative or precisely null relationships between changes in service delivery and changes in the ANC's vote share. In general, it also seems from our sample that voters are more sensitive to changes in water than changes in refuse and sewerage, as the magnitudes are generally larger.

All coefficients - both for the full sample and the competitive sample - are negative and statistically significant at conventional levels in table 3. In terms of magnitude, the findings are also notable. Consider column 1 of table 3 , in which a -0.146 coefficient implies a decrease in ANC vote share of 14.6 percentage points were water coverage to move from 0 (no coverage) to 1 (full coverage). The mean change in water provision from 2001 to 2011 at the ward level was an increase of roughly 0.12 , or 12 percentage points. Thus a change of mean magnitude would result in an estimated average decrease of $14.6 \times 0.12$, roughly 1.75 percentage points of ANC vote share.

\subsection{Heterogeneity By Local Municipal Incumbent}

We next decompose these results in two ways. First, we consider heterogeneity in the effect of increased service delivery by local municipal incumbency status. We define "opposition municipal control" as the ANC not having the majority of seats in the municipal council over the entire period 2000 to 2011.15 To recover the heterogeneity in effects, we re-estimate our previous specifications on the two sub-groups, ANC controlled municipalities and those that we not. The results are

\footnotetext{
${ }^{15}$ Building this measure was non-trivial, because municipalities change boundaries over time. We dealt with this as follows. First, for each of 2000 and 2006, we found all municipalities whose boundaries had stayed constant until 2011. For these cases, we did not need to make any changes and left them as they were. For the municipalities that had changed, we first reconciled the 2000 and 2006 municipalities with the 2011 municipalities. Fortunately, the number of municipalities has declined over the years, which means that, for the most part, multiple 2000 and 2006 municipalities are contained within single 2011 boundaries. We established which 2000 and 2006 municipalities belong to which 2011 municipalities, and then took the mean of the seatshare for all old municipalities, and the sum of seats occupied by the ANC and total seats. This created a set of 2011 municipal-level variables that measure the total number of seats occupied by the ANC in each of 2000 and 2006, the total number of available seats, and the average (over old municipalities) of seatshares.
} 


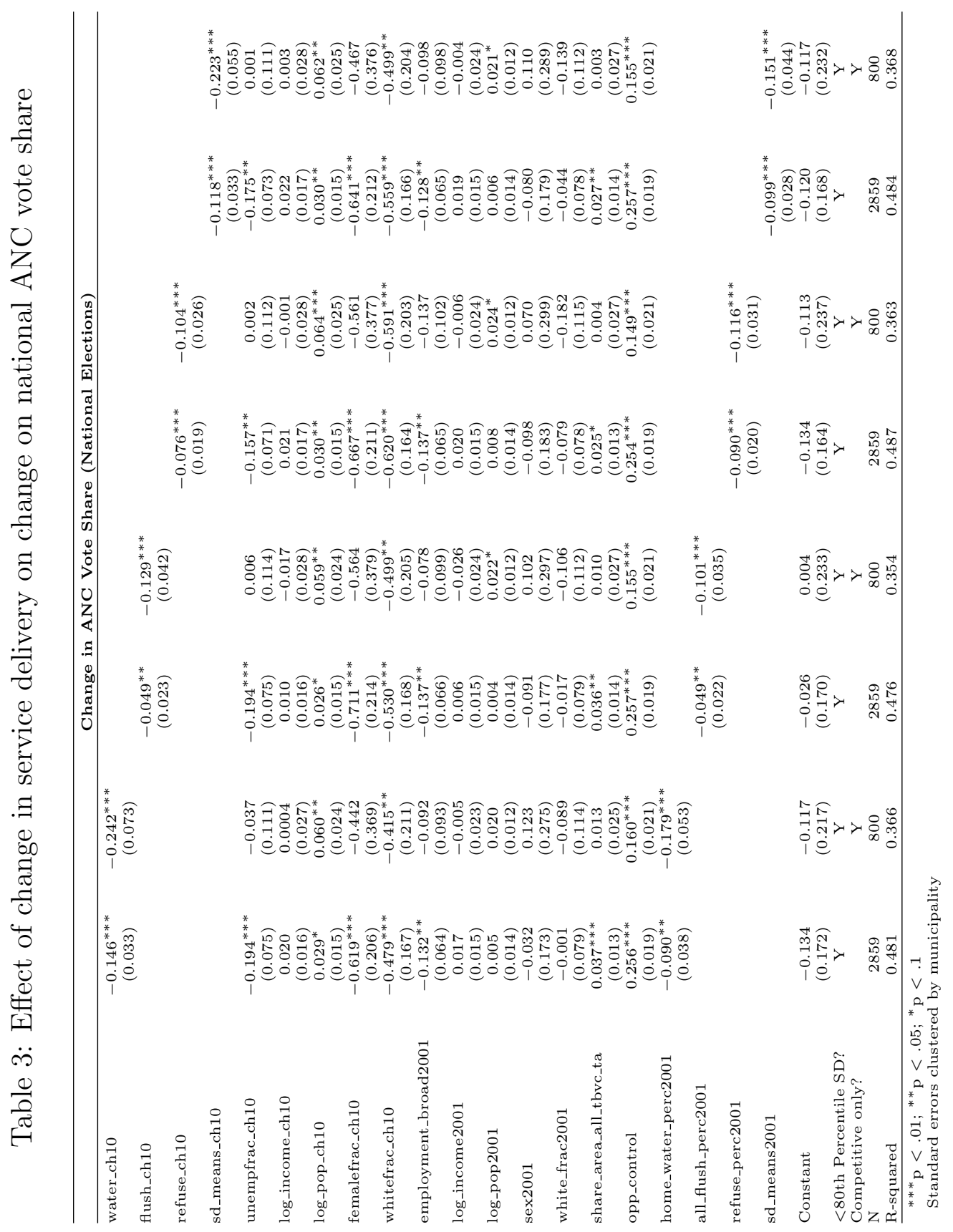


presented in panels $\mathrm{A}$ and $\mathrm{B}$ of table $4{ }^{16}$

The results in the top four rows of panels A and B largely corroborate the previous findings the ANC loses vote share when service delivery improves. Note, however, that the magnitudes of the coefficients in panel B (those areas not systematically controlled by the ANC) are somewhat larger than the coefficients estimated in panel A (ANC areas), suggesting, quite plausibly, that those living in opposition areas respond more intensely to changes in service delivery than those not.

We next consider the effect of service delivery in local elections. These results, from the same specifications outlined above and again decomposed by municipal incumbency status (ANC or opposition controlled), are presented in panels $\mathrm{A}$ and $\mathrm{B}$ of table 5 . At the local level we find that increases in water provision affects ANC vote share negatively - albeit the effect appears to be about half as strong as in the national elections. For other services the effect estimates are approximately zero - sometimes slightly positive, sometimes slightly negative, never statistically distinguishable from zero.

By contrast, in opposition areas, the negative effects remain with substantively similar magnitudes, and statistically distinguishable from zero. This suggests to us that in local elections improvements in service delivery only affect the national incumbent's vote share in areas they do not systematically control - opposition areas. The dominant party does gain electoral advantage for increased service provision in these local contests.

This difference in effects in local and national elections requires some further consideration. Why do negative effects appear across the board in national elections but less so in ANC controlled municipalities in local elections? There area a number of plausible explanations, most notably

\footnotetext{
${ }^{16}$ In alternative specifications we used the full samples and included an interaction term (opposition municipal control $\times$ service delivery change) to allow the effect of changes in service delivery to affect ANC vote share heterogeneously. The results are similar, but we suspect that the interaction term is not particularly suitable in this setting due to a lack of common support, so the subset analyses are preferred (Hainmueller, Mummolo and Xu|2016).
} 


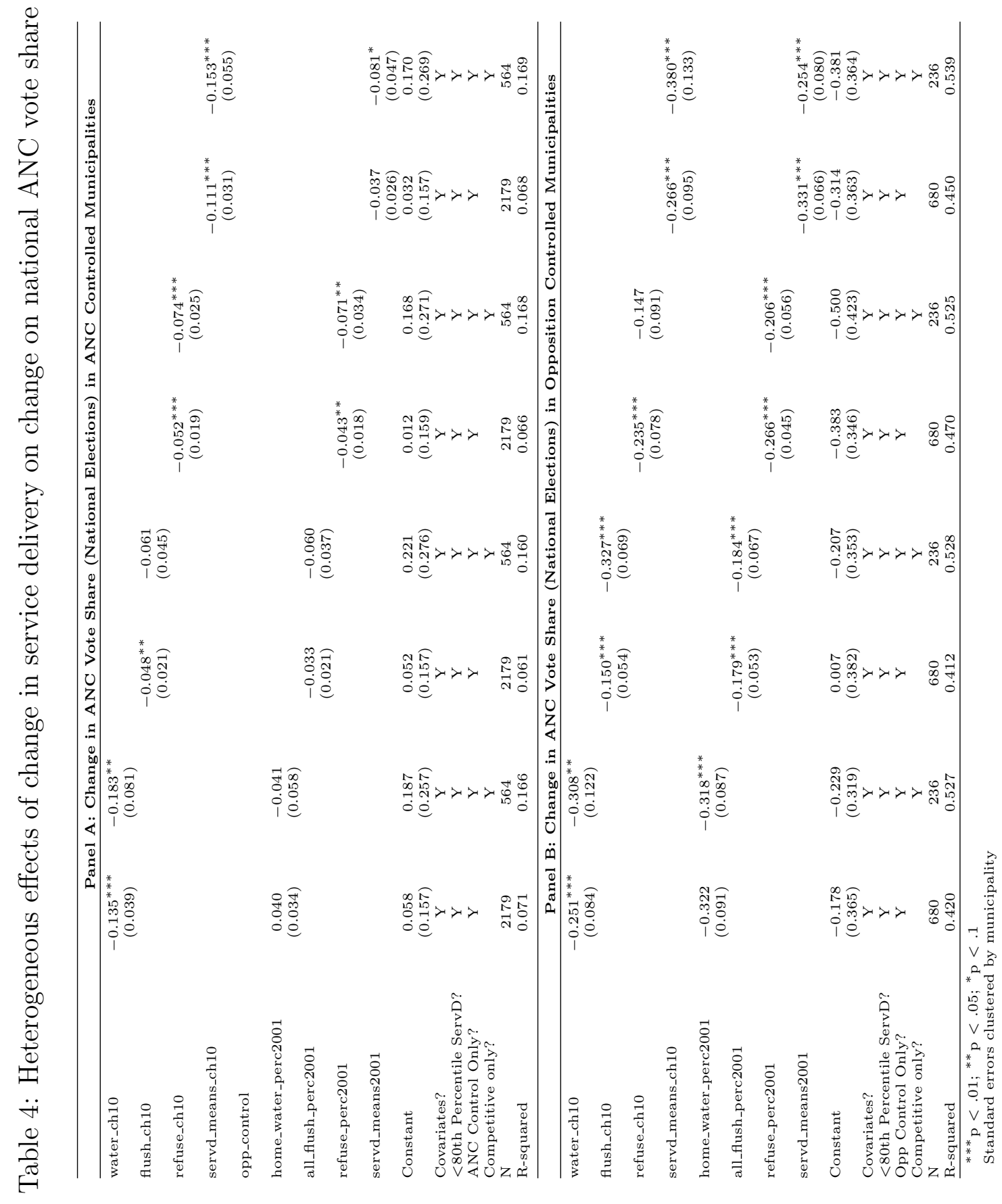




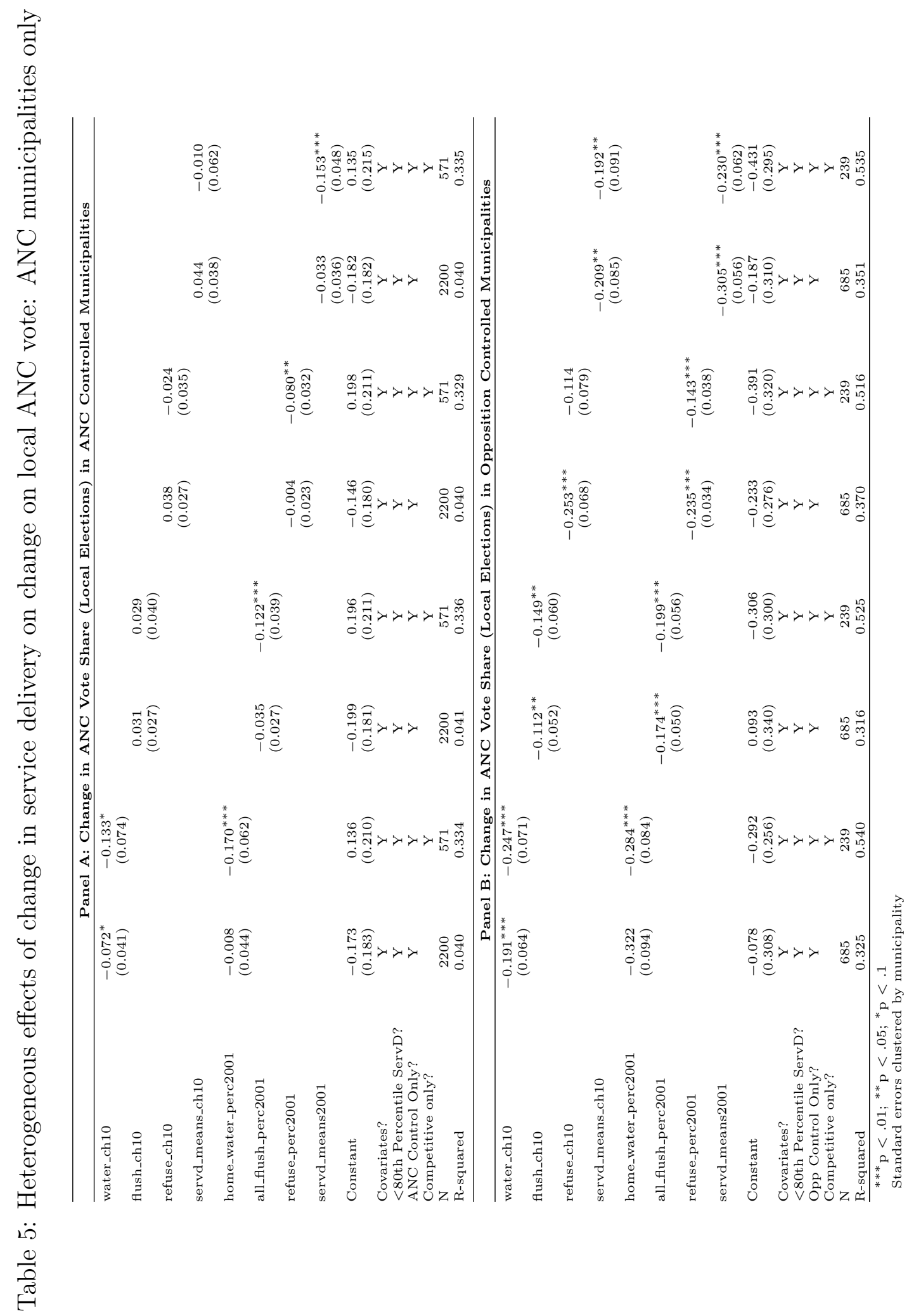


that the electorates in national and local contests (which are off-cycle) are different. Turnout in South Africa is roughly half as high in local elections as national elections, suggesting that there may be strong self-selection into the local electorate. These voters may be stronger partisans (who are more likely to vote, and more likely to be activated by the machine), more sophisticated and knowledgeable, and thus better able to make sharper inferences about who is responsible for service delivery. Whatever the source of the difference, we see these two sets of results as complementary, together suggesting that the ANC is, at the very least, not rewarded for service provision.

This one subtlety notwithstanding, our results generally suggest an across the board negative effect of service delivery provision on ANC vote share, stronger in opposition controlled areas and in national elections.

\section{Analyses of Individual-Level Survey Data}

The analyses and discussion above highlight that gains in government-provided service provision are generally inversely related to changes in ANC vote share. The negative relationships are plausibly understandable in the context of opposition-controlled municipalities, though even in these cases they require that voters differentially allocate responsibility between the ANC-led national government and opposition-led local governments, a task which may be difficult given the centralized nature of the country and that service delivery has been a central ANC issue since 1994. Moreover, the general lack of a positive relationships between service delivery and vote share even in ANC-controlled municipalities remains surprising from the perspective of conventional electoral accountability theories.

In reflecting on such analyses as a basis for understanding individual attitudes and behavior, it is important to consider whether our results might simply be driven by some ecological fallacy. Given this, is there evidence that individual voters respond in a similar manner? Using Afrobarometer data we take advantage of survey responses to questions about household service access as well 
as enumerator-reported assessments of service infrastructure. In order to analyze the effects of local-level coverage (as discussed in the prior section), we spatially joined our aggregate service delivery data to the Afrobarometer $\left[{ }^{17}\right.$

We initially focus on six outcome variables described in table 6, where the first two are used interchangeably depending on the particular service of interest (water/sanitation or refuse). In the third column of the table, we indicate the number of valid response items - for example, ranging from "very unfavorable" to "very favorable." All variables are re-coded for analysis on a $0-1$ scale, and the vote_ANC variable is recoded as a dummy variable that takes a value of 1 for all respondents indicating the African National Congress party, and a value of 0 for all other responses.

The use of survey data complements the analyses presented earlier, but some limitations are notable: Despite the availability of five rounds of survey data, we cannot measure over-time changes in public opinions and voting intentions at the individual level because the Afrobarometer survey is not a panel. Further, some areas are added and some dropped over time. And because representative random sampling for the survey is conducted only at the district level, and sample sizes at the municipal- or ward-levels are small, we cannot assemble an areal panel to analyze changes in opinion at that level.

As such, we use the Afrobarometer in a pooled cross-sectional fashion, including various time and area fixed effects, along with a rich set of covariates, to absorb as much variation and potential confounding as possible. We adopt a simple ordinary least squares approach to estimation.18

\footnotetext{
${ }^{17}$ Specifically, we join round 5 (2011) with 2011 census data; and we join rounds 2 (2000) and 2.5 (2004) with 2001 census data. When conducting analyses using these aggregate data, we exclude rounds 3 (2006) and 4 (2009) owing to lack of corresponding data for those years.

${ }^{18} \mathrm{We}$ use OLS for all specifications because the coefficients are easier to interpret than, for instance, logit or probit, and the results should not be substantially affected by this choice. We do obtain substantively similar results when estimating these relationships with logistic regression for the binary vote choice outcome.
} 
Table 6: Individual-level outcome variables

\begin{tabular}{|c|c|c|}
\hline Variable & Definition & $\begin{array}{l}\text { Number } \\
\text { resp } \\
\text { choices }\end{array}$ \\
\hline gov_watsanit & $\begin{array}{l}\text { "How well or badly would you say the current government is } \\
\text { handling the following matters, or havent you heard enough } \\
\text { to say: Providing water and sanitation services? }\end{array}$ & 4 \\
\hline loc_gov_refuse & $\begin{array}{l}\text { "What about local government? I do not mean the national } \\
\text { government. I mean your municipal or local government coun- } \\
\text { cil. How well or badly would you say your local government is } \\
\text { handling the following matters, or haven't you heard enough } \\
\text { about them to say: Keeping our community clean, for exam- } \\
\text { ple, by having refuse removed?" }\end{array}$ & 4 \\
\hline ownliving & $\begin{array}{l}\text { "In general, how would you describe: Your own present living } \\
\text { conditions?" }\end{array}$ & 5 \\
\hline loc_coun_rate & $\begin{array}{l}\text { "Do you approve or disapprove of the way the following people } \\
\text { have performed their jobs over the past twelve months, or } \\
\text { havent you heard enough about them to say: Your elected } \\
\text { local government councilor?" }\end{array}$ & 4 \\
\hline prez_rate & $\begin{array}{l}\text { "Do you approve or disapprove of the way the following peo- } \\
\text { ple have performed their jobs over the past twelve months, } \\
\text { or havent you heard enough about them to say: President } \\
\text { Mbeki/Zuma?" }\end{array}$ & 4 \\
\hline vote_ANC & $\begin{array}{l}\text { "If a presidential election were held tomorrow, which party's } \\
\text { candidate would you vote for?" }\end{array}$ & open \\
\hline
\end{tabular}


The Afrobarometer provides two types of data for analyzing services: Direct questions to respondents about household service access, and enumerator-recorded data about the presence or absence of visible services in the enumeration area. In terms of the former, we consider responses to questions about the presence of water for household use as being outside the compound, inside the compound, or inside the house (responses coded as 0, 0.5, and 1.0 respectively) and about the presence of a toilet or latrine, allowing for answer of none, outside the compound, inside the compound, or inside the house (responses coded as 0,0.33, 0.67, and 1.0). And in terms of enumeration area data, we consider binary response variables to questions about the presence or absence of a piped water system and a sewage system.

We are able to join individual-level data from several rounds with the geo-coded service delivery data analyzed in the previous section, which allows us to analyze the relationship between service delivery patterns (at the individual, enumeration area, ward, and municipal levels) and individual attitudes, perceptions, and behavioral intentions. Thus, in contrast to the analyses presented in section 4 , in which we estimated the effects of changes, in the current section, we present estimates of the relationship between levels of service provision and individual attitudes and behavioral intentions. Nonetheless, because the vast majority of black South Africans lacked such services in the immediate post-apartheid period, we believe that that in analyses of this group, observed service levels are a good proxy for within-household change in service delivery.

\subsection{DATA QUALITY}

Before presenting our individual-level analyses of service provision and voter attitudes and behaviors, it is useful to reflect on the quality and credibility of our data more generally. Sandefur and Glassman 2013 cast substantial doubt on various sources of African data by highlighting discrepancies between survey and administrative statistics. Obviously, scholars working in the region must take such concerns seriously; particularly when finding counter-intuitive results one possible explanation must be that the data were bad - poorly measured, intentionally or unintentionally 
falsified. We agree with Sandefur and Glassman 2013) that an important strategy for assessing the quality of data is to compare independently conducted administrative and household surveys that measure similar items. Having joined several rounds of Afrobarometer data with two rounds of South African census data, we are able to do just that with respect to two important services: access to piped water and toilets.

As shown in figure 2, we grouped the merged data into bins according to the census-reported, ward-level coverage of piped water services and flush toilets, and then for each bin (ranging from zero-to-less than 10 percent coverage to 90 -to-100 percent coverage), we plotted the distribution of individual-level responses to Afrobarometer questions about the respective services.

The figure shows plainly that there is a very tight correspondence between the two data sources (of course, the statistical correlations are high and significant, but this portrait is far more nuanced). While of course other problems of measurement reliability and validity may arise, this strong correspondence lends a high degree of credibility to the data sources, and provides an opportunity for us to probe the findings described above with analyses of the Afrobarometer survey data.

\subsection{South African Results}

Our analyses of individual-level data are highly consistent with the aggregate-level analyses presented above. Specifically, we estimated models of our key outcome variables as a function of service delivery and a series of individual-level covariates. For these analyses we restrict our analyses to black South Africans because individuals from this group were most likely to lack services at the start of the period under consideration, and to be concerned about services as a basis for vote choice. Following the findings described above, we compare results for those in ANC-controlled and opposition-controlled municipalities.

In figure 3, we report our analyses of the effects (under some assumptions) of self-reported service delivery data at the household and enumeration-area levels. Across ANC- and opposition- 
Figure 2: Distribution of Individual Afrobarometer Responses to Service Provision Questions by Census-reported Service Coverage

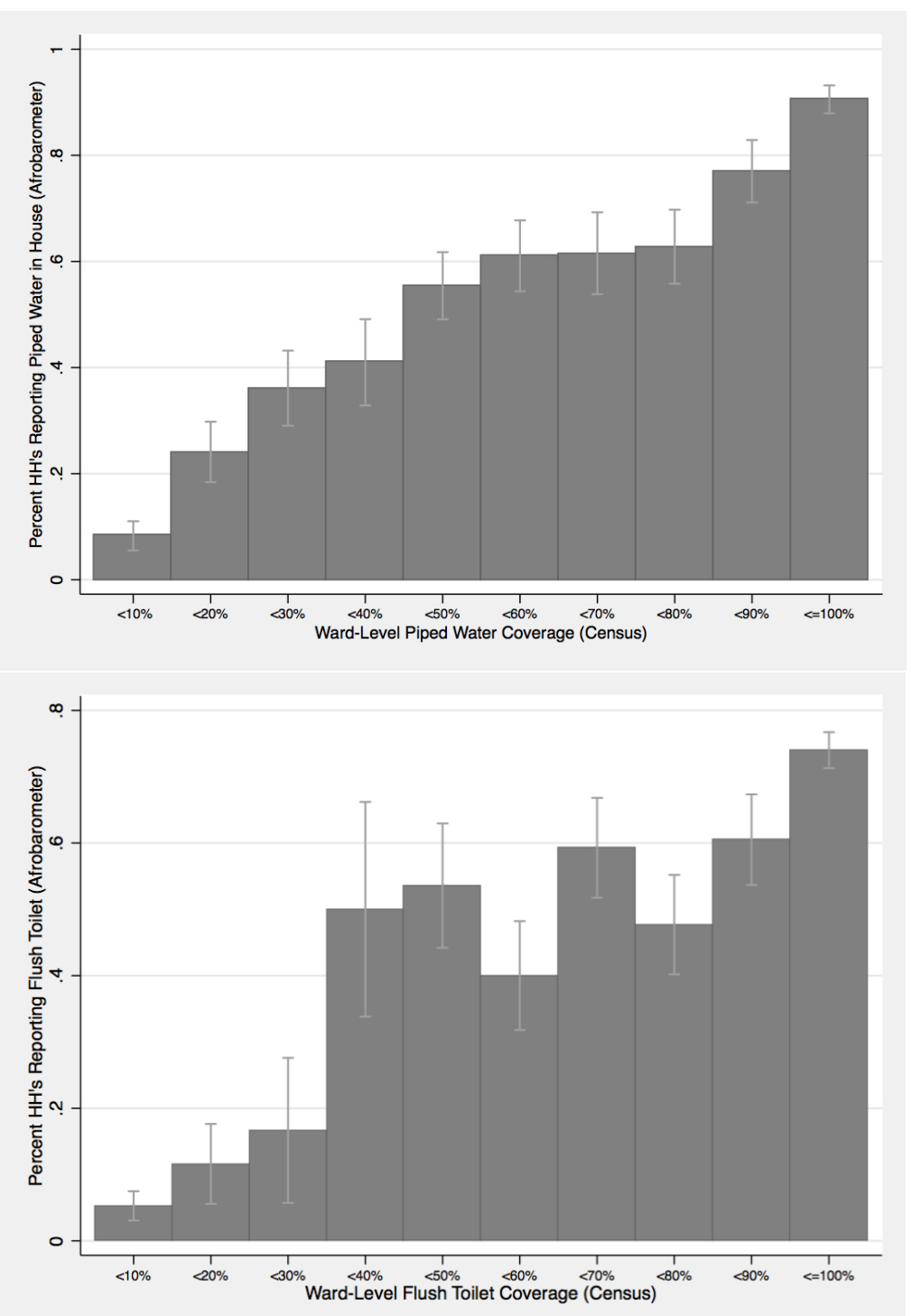

Bars represent the percentage of respondents on the Afrobarometer surveys who said they had listed services inside their house, and lines represent 95 percent confidence intervals, grouped according to each houshold's location in a ward that was reported on the census to have a particular coverage of that service. Data from 2011 South African census and 2012 Afrobarometer survey. 
controlled areas, having services in the household or in the enumeration area positively predicts how likely the individual is to rate the quality of water and sanitation services (though the estimated effect of water in opposition-controlled areas is zero). We interpret these findings as strong evidence that there is not an informational problem (of the type discussed in our earlier theoretical section) at hand: citizens are aware of the services they are receiving and, consciously or not, they attribute those services at least in part to government action.

At the household level, we do not find conclusive relationships between service access and attitudes about living conditions or ratings of government. However, when considering service infrastructure in the enumeration area, this is generally associated with better individual ratings of living conditions across all types of wards. Service provision does not have a particularly consistent association with ratings of local councilors or of the president, but some estimates are positive in the context of opposition-controlled municipalities.

Most strikingly, for the vote-intention dependent variable, in 7 of 8 estimates, we find a negative relationship between service access and intention to vote for the ruling ANC party in a hypothetical presidential election, and these are all substantively and statistically significant in the 4 estimates of the effect of household service access.

From the perspective of conventional theories of electoral accountability, it is not entirely surprising that in opposition-controlled areas that voters would credit good service to the opposition party, leading a greater share of potential ANC voters towards the opposition. That said, it is not fully obvious that they should respond in this way given that basic service provision was articulated as a national priority by the ruling ANC party and a substantial share of funds available to local governments are transferred from the national government (as discussed above).

What is certainly surprising from the perspective of conventional theories of electoral accountability is that even in ANC-controlled areas, where party-based attribution is unambiguous, we still find a sizeable, negative and statistically significant relationship between service provision 
and intention to vote for the ANC. And these patterns fully accord with the results we observed in our aggregate analyses.

To demonstrate that our results are not driven by specific modeling assumptions, we re-estimate the effects of individual-level service access using matching within our sample of individual respondents (Ho et al. 2007), but owing to sample size constraints, only within ANC-controlled areas. That is, we consider "treatment" to be access to a particular service, and we pre-process our data to identify respondents who are similar in all observable characteristics that could simultaneously predict treatment and outcomes ${ }^{19}$ Again, we cannot claim that treatment is randomly assigned, but our matching analyses more closely resemble an experimental design.

Although pre-processing comes at a substantial cost in terms of loss of sample size, as we show in figure 4, we find again that individual-level access to services is associated with substantially better ratings of government services, but also substantial decreases in likelihood of voting for the ANC. We present the estimates of average treatment effects on treated individuals (ATT) and find that the probability of voting ANC is reduced by 16.6 percentage points for those with water, and by 18.2 percentage points for those with toilets.20

In short, the dominant party in power not only fails to get voting credit in the oppositioncontolled localites, but even where it is unambiguously in control and responsible for government service, service access is associated with greater likelihood of an opposition vote.

\footnotetext{
${ }^{19}$ In the appendix we show the results of pre-processing our data based on exact matching on a number of key covariates: municipality, survey wave, a dummy variables for having completed secondary school, whether the respondent is living in an urban area, has a cash-paying job, or speaks Zulu at home. As demonstrated in the appendix, matching accomplishes substantial improvements in balance, with no substantively or statistically significant differences remaining across treated and untreated groups. The fact that we achieve improved balance even for variables that we did not explicitly match on lends additional credibility to the assumption behind our subsequent analyses, that these groups are extremely similar, except in terms of treatment assignment condition.

${ }^{20}$ Of course, whether or not these estimates are actually causal depends on whether we have satisfied selection on observables - conditioning on all confounders. We return to this question in the next section.
} 
Figure 3: Service Access Effects on Attitudes and Voting Intentions of Black South Africans
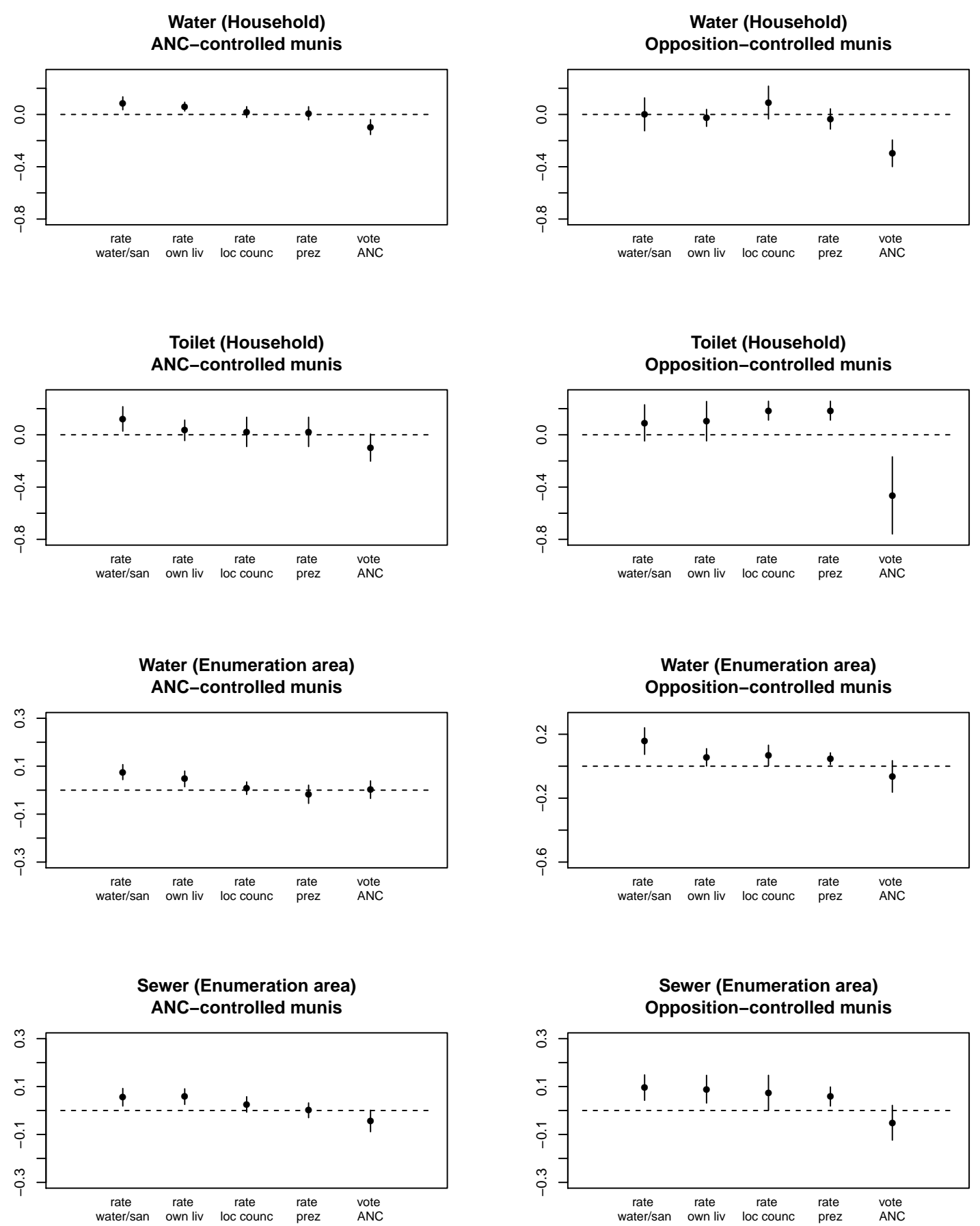

Each panel presents estimated coefficients from five OLS regressions. In each regression, the titled service delivery item is the independent variable, and the survey response listed on the $\mathrm{X}$-axis is the dependent variable. Each coefficient is estimated with survey wave and municipality fixed effects, and standard errors are calculated by clustering data at the municipality-level. Lines represent 95 percent cluster-robust confidence intervals. Individual-level controls include gender, age, education-level, dummy variables for home language (Xhosa or Zulu, with other as missing category), and urban residence. Note that data about own water were only contained in rounds 4 and 5; and data about own toilets were only contained in wave 5 . 
Figure 4: Household, Enumeration-Area Service Delivery and Citizen Attitudes and Intentions, Matching Estimates (ANC-Controlled Municipalities)
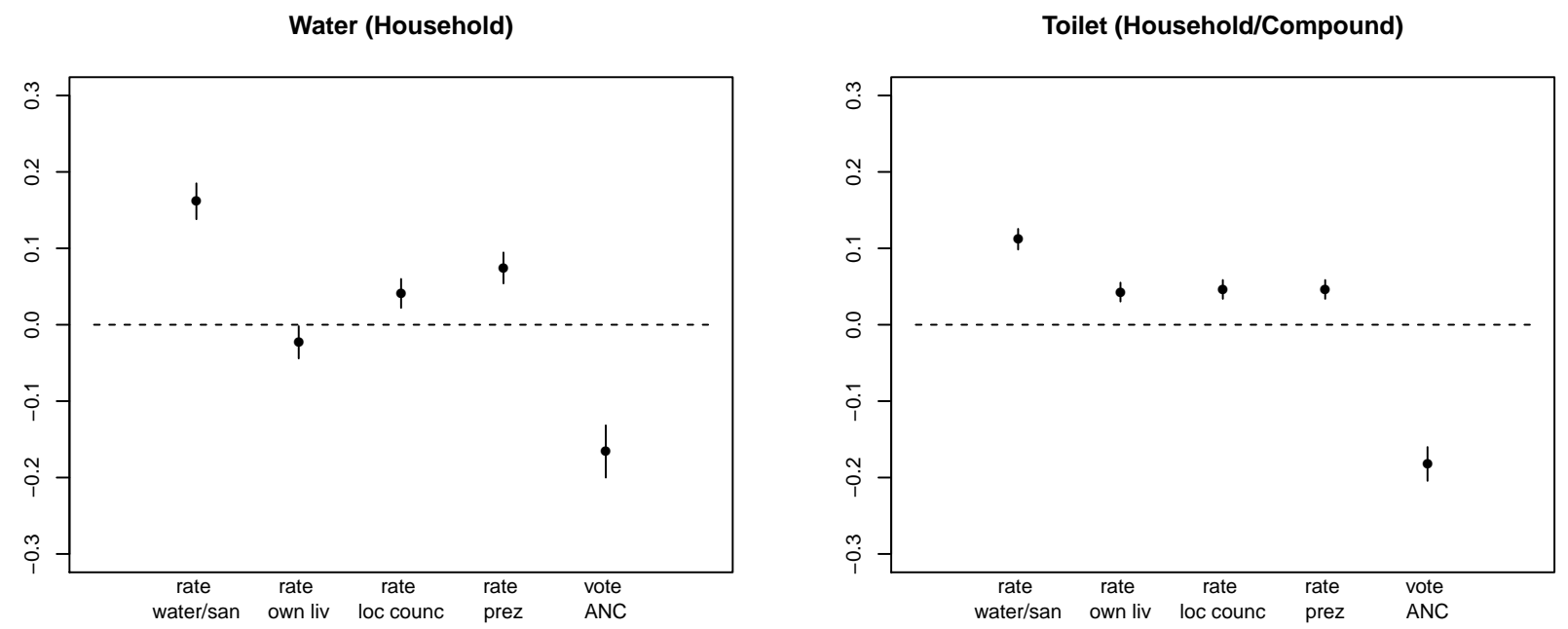

Each panel presents ATT estimates of the listed service delivery item from calculations of difference in means between "treated" and "untreated" groups. Afrobarometer survey items listed on the $\mathrm{X}$-axes are the outcome variables from separate analyses. Lines represent 95 percent confidence intervals. 


\subsection{General patterns in Southern Africa}

Do our findings generalize to the rest of democratic Southern Africa? Botswana, Namibia, and Lesotho are all similar to South Africa in important ways: they are all middle-income countries, characterized by substantial within-country variation in service delivery; with improvements in delivery in recent years; with a dominant but slowly declining liberation party in power; and relatively strong democratic institutions and rule. While fine-grained voting and service delivery data are not currently available to us for any of Botswana, Namibia, or Lesotho, we are able to test the extent to which our findings apply at the individual-level, using data from the Afrobarometer.

To the extent possible, we replicate our individual-level analyses, though given the relatively small population sizes and absence of regional data, we do not control for regional fixed effects or cluster standard errors at a regional level. Exactly as before, we estimate a series of regressions of individual ratings of government water and sanitation services, individuals' self-ratings of their own living conditions, ratings of their local government officials, ratings of the president, and finally, their stated inclination to vote for the ruling party in the next election. (We are not able to subset these analyses according to local government control, however.)

As summarized in table 7, and elaborated in a series of more detailed tables in the Appendix, we find strikingly similar relationships in all three countries to what we find in the South African case. When individuals have access to water or toilet services in their own homes, or if water or sewerage infrastructure is available in the enumeration area in which the respondent resides, individuals are more likely to rate government water and sewerage services as being significantly better as compared with the ratings provided by those without such services. (19 of 20 estimates are positive, 17 significant).

However, as we move across the columns from left-to-right, that is, from evaluation of services to support for incumbents, we see that the effects generally shift from positive-to-negative. In particular, we find that service provision is associated with negative effect on incumbent party 
Table 7: Replicating results in other Southern African Democracies. Cells report OLS regression estimates, with standard errors in parentheses. Each cell is from a separate country-level regression, and full tables are reported in the Appendix.

\begin{tabular}{|c|c|c|c|c|c|}
\hline & rate water/san & rate own living & rate local council & rate president & vote rule party \\
\hline \multicolumn{6}{|l|}{ Botswana } \\
\hline own water & $\begin{array}{c}0.100^{* * *} \\
(0.018)\end{array}$ & $\begin{array}{c}0.130^{* * *} \\
(0.017)\end{array}$ & $\begin{array}{c}0.014 \\
(0.021)\end{array}$ & $\begin{array}{l}-0.028 \\
(0.019)\end{array}$ & $\begin{array}{c}-0.082^{* *} \\
(0.033)\end{array}$ \\
\hline ea_water & $\begin{array}{c}0.044^{* * *} \\
(0.012)\end{array}$ & $\begin{array}{c}0.014 \\
(0.012)\end{array}$ & $\begin{array}{l}0.027^{*} \\
(0.014)\end{array}$ & $\begin{array}{c}0.003 \\
(0.014)\end{array}$ & $\begin{array}{l}-0.042 \\
(0.028)\end{array}$ \\
\hline own toilet & $\begin{array}{c}0.075^{* *} \\
(0.031)\end{array}$ & $\begin{array}{c}0.185^{* * *} \\
(0.027)\end{array}$ & $\begin{array}{c}0.036 \\
(0.037)\end{array}$ & $\begin{array}{l}-0.040 \\
(0.035)\end{array}$ & $\begin{array}{c}-0.127^{* *} \\
(0.057)\end{array}$ \\
\hline ea_sewer & $\begin{array}{c}0.046^{* * *} \\
(0.009)\end{array}$ & $\begin{array}{c}0.038^{* * *} \\
(0.009)\end{array}$ & $\begin{array}{c}0.015 \\
(0.011)\end{array}$ & $\begin{array}{l}-0.013 \\
(0.010)\end{array}$ & $\begin{array}{c}0.022 \\
(0.020)\end{array}$ \\
\hline \multicolumn{6}{|l|}{$\underline{\text { Lesotho }}$} \\
\hline ea_water & $\begin{array}{c}0.102^{* * *} \\
(0.012)\end{array}$ & $\begin{array}{c}0.018^{* *} \\
(0.009)\end{array}$ & $\begin{array}{c}0.003 \\
(0.014)\end{array}$ & $\begin{array}{l}-0.016 \\
(0.012)\end{array}$ & $\begin{array}{c}-0.062^{* *} \\
(0.030)\end{array}$ \\
\hline ea_sewer & $\begin{array}{c}0.057^{* * *} \\
(0.020)\end{array}$ & $\begin{array}{c}0.009 \\
(0.015)\end{array}$ & $\begin{array}{l}-0.010 \\
(0.028)\end{array}$ & $\begin{array}{l}0.0003 \\
(0.021)\end{array}$ & $\begin{array}{l}0.110^{*} \\
(0.057)\end{array}$ \\
\hline \multicolumn{6}{|l|}{$\underline{\text { Namibia }}$} \\
\hline own water & $\begin{array}{c}0.143^{* * *} \\
(0.018)\end{array}$ & $\begin{array}{c}0.143^{* * *} \\
(0.018)\end{array}$ & $\begin{array}{c}0.010 \\
(0.017)\end{array}$ & $\begin{array}{l}0.026^{*} \\
(0.015)\end{array}$ & $\begin{array}{l}-0.033 \\
(0.028)\end{array}$ \\
\hline ea_water & $\begin{array}{c}0.035^{* * *} \\
(0.010)\end{array}$ & $\begin{array}{l}-0.010 \\
(0.010)\end{array}$ & $\begin{array}{l}-0.016 \\
(0.011)\end{array}$ & $\begin{array}{l}-0.004 \\
(0.008)\end{array}$ & $\begin{array}{c}-0.049^{* * *} \\
(0.019)\end{array}$ \\
\hline own toilet & $\begin{array}{c}0.137^{* * *} \\
(0.030)\end{array}$ & $\begin{array}{c}0.167^{* * *} \\
(0.030)\end{array}$ & $\begin{array}{l}-0.011 \\
(0.028)\end{array}$ & $\begin{array}{c}0.059^{* *} \\
(0.025)\end{array}$ & $\begin{array}{l}-0.011 \\
(0.047)\end{array}$ \\
\hline ea_sewer & $\begin{array}{c}0.072^{* * *} \\
(0.014)\end{array}$ & $\begin{array}{c}0.053^{* * *} \\
(0.013)\end{array}$ & $\begin{array}{c}0.014 \\
(0.014)\end{array}$ & $\begin{array}{c}0.006 \\
(0.011)\end{array}$ & $\begin{array}{l}-0.014 \\
(0.025)\end{array}$ \\
\hline
\end{tabular}

${ }^{* * *} \mathrm{p}<.01 ;{ }^{* *} \mathrm{p}<.05 ;{ }^{*} \mathrm{p}<.1$ 
support in eight of the 10 estimates, four of which are significant at the 95 percent level. As in South Africa, citizens in other Southern African democracies appear to be less likely to vote for the party in power when they report access to infrastructural service.

\subsection{Discussion}

Having now described several sets of empirical results, at different levels of analysis and using different data, how do these fit together with respect to conventional predictions concerning the relationship between government service delivery and voter responses? Our empirical findings do not follow easily the basic premises of theories of electoral accountability. At both the aggregatelevel and the individual-level, across four country cases, we find almost no evidence of any positive association between access to service delivery and intentions to vote for the incumbent party. This is particularly surprising in light of the fact that both our aggregate and individual-level measures of service provision are associated with self-reports of access to, and quality of, services. In other words, these services are visible to voters, and they attribute government effort to that service provision. However, this information does not positively predict a vote for the dominant incumbent party.

Can this collection of findings be interpreted as causal? Our research design combines firstdifference analyses at the ward-level with complementary individual-level cross-sectional analyses, conditioning on a range of possible confounders. Nonetheless, service delivery is clearly not randomly assigned, and our findings, both aggregate and micro, could possibly be confounded by factors that simultaneously affect changes/levels of service provision and changes/levels of votingrelevant attitudes and behaviors.

For example, our results could be confounded if the purposeful strategy of South Africa's ANC was to target service delivery in areas of growing discontent with its government such that where we see increased service provision, we find declines in government support that was not itself a response to service delivery. Frankly, this seems implausible, particularly in light of the discussion presented 
in section 3.1. Moreover, given the consistency of our results at the individual-level, in which we control for municipality fixed effects, we do not believe it would be possible for the government to target services so narrowly in favor of possible discontents that this could be picked up in our analyses, and additional qualitative research further convinces us of the unlikelihood of this alternative explanation. Crucially, our results are also not confounded by differential baselines of service delivery. That is, the first-difference regressions absorb all time-invariant confounders, but we are also able to include baseline covariate regressors to weaken the parallel trends assumption at the heart of our analyses.

One final candidate confounder is that service delivery is largely a function of unobserved individual skill in demanding and obtaining services. If this were the case, those who receive services may be truly different from those who did not, even prior to receipt of services. It is not obvious to us why such individuals, having received services, would be more likely to vote against the ANC. By controlling on observables we have tried to guard against such differences. In sum, then, we feel relatively confident that our results are not driven by confounders, but address the fundamental relationship between service provision and voting behavior. Nonetheless, our central contribution has been to demonstrate a robust and counter-intuitive association in an important, natural setting, one that is substantively important for understanding the relationship between democratic governance and human development. Before suggesting avenues for future research, we turn to the important question of trying to explain why we may have observed these patterns in our data.

\section{Theoretical Elaboration: Explaining the Weakness of Electoral}

\section{ACCOUntability}

While it is one thing to find that service delivery has no observable effect on attitudes or behaviors towards the incumbent, we find a negative association between service provision and incumbent voting. As discussed earlier, this may not be particularly surprising in localities controlled by the 
opposition if service provision is (perhaps deservedly) credited to that party. But the persistence of either null or negative relationships in incumbent-controlled areas demands further explanation. And as discussed earlier, we emphasize that we initiated our theorizing only after observing the surprising results. In this section, we outline, and offer tentative probes of a range of plausible mechanisms, and here we focus on the South African case, again because of the richness of data available to us. (And we restrict our analyses to black South Africans in ANC-controlled municipalities.)

We consider two core sets of explanations, those that focus on voter preferences and perceptions, and those that focus on strategic behavior by voters and parties. We find preliminary evidence for two key mechanisms: first, that citizens who receive services are more likely to change their preferences and expectations for what they want from government, which in turn leads to dissatisfaction with the incumbent party; and second, that the process of delivering new services puts citizens in closer contact with the machinations of government, which leads them to perceive more corruption, which in turn pushes them away from the incumbent.

\subsection{PREFERENCES AND PERCEPTIONS}

The core model of democratic accountability posits that citizens desire services, and if they receive them they will be happy (or satisfied). In turn, they will decide that they have identified a competent government that can provide for their needs, and will ultimately vote to re-elect the incumbent. If, however, voters do not receive services, they will search for an alternative government. The results we have presented above directly contradict this model. As such, it is necessary to specify a more subtle, and more dynamic, model of citizen preferences and perceptions.

\subsubsection{Relative deprivation}

One possible shortcoming of the conventional model of democratic accountability is that it does not calibrate preferences in a relational manner. Individuals' overall satisfaction with government 
may be strongly conditioned by a sense of relative deprivation and privilege, which in turn tends to be affected by what others around them are receiving Stewart 2006, Ravallion and Lokshin 2010. For example, it is possible that the aggregate results reflect intensified dissatisfaction among those without services in areas that are enjoying higher levels of service provision. In a similar vein, perhaps voters only reward the incumbent for infrastructural investment in services when such services are excludable, and when they are members of the group with access. That is, if almost everyone in the community enjoys services, the level of provision becomes "normalized" and individual citizens may be less likely to reward the incumbent government.

In order to assess this proposition, we consider how individual citizens respond to the outcomes analyzed above, but in response to changes in aggregate level service provision at the municipality and ward levels. As reported in figure 5, we find some important similarities, and also some potentially revealing differences when compared with analyses of the effects of service provision at the household level. We find that higher levels of municipal coverage for individual $i$ 's municipality and ward generally predict higher individual ratings of the respective government services. In general, vote intentions and ratings of local council or president are not strongly predicted at the individual level by these aggregate data (with few significant results), though the point estimates of the relationship with ANC vote intention are still uniformly negative.

And yet, interestingly, those individuals living in municipalities with higher levels of service delivery are more likely to report substantially lower satisfaction with their individual living conditions. We do not observe this relationship with respect to ward-level data, which provides a more proximate portrait of the infrastructural environment in which the respondent resides. Clearly, this suggests, all else equal, that as municipal conditions improve, black South Africans are less likely to rate their own living conditions favorably, which is consistent with a "relative deprivation" effect.

However, if relative deprivation were truly driving the core results with respect to voting intentions and behaviors, we would expect to observe a negative effect from service coverage levels on 
Figure 5: Local-level Service Coverage Effects on Citizen Attitudes and Voting Intentions
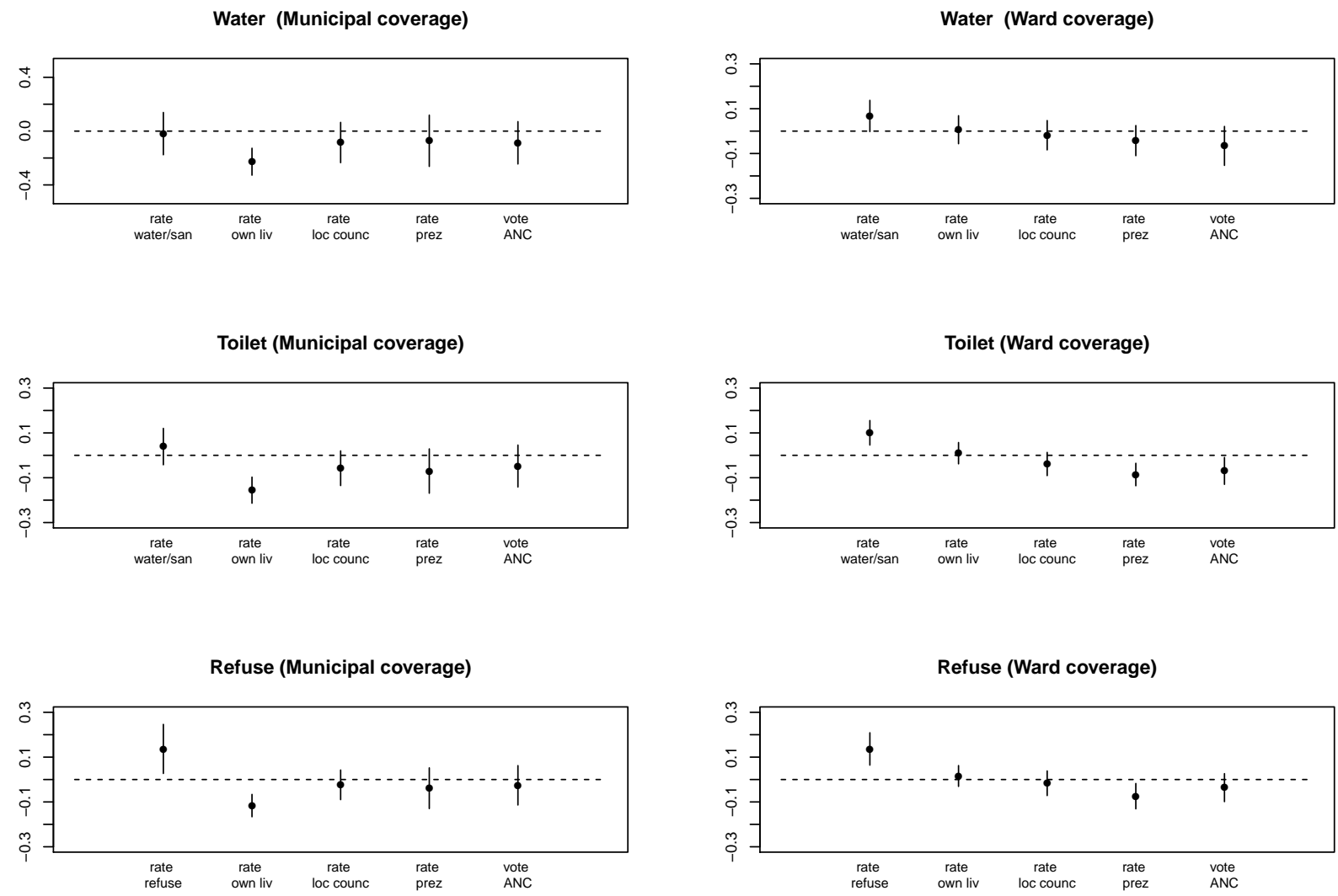

Each panel presents estimated coefficients from five OLS regressions. In each regression, the titled service delivery item is the independent variable, and the survey response listed on the $\mathrm{X}$-axis is the dependent variable. Each coefficient is estimated with survey wave fixed effects, and standard errors are calculated by clustering data at the municipality- or ward-level (depending on analysis). Lines represent 95 percent cluster-robust confidence intervals. Individual-level controls include gender, age, education-level, dummy variables for home language (Xhosa or Zulu, with other as missing category), and a dummy variable for urban residence; and at the municipal-level, we control for $\log$ of population. Recall that these regressions only include round $2,2.5$, and 5 . 
likelihood of ANC voting among those who lack services. In fact, as reported in Table 8, we find that while higher levels of municipal-level service coverage are associated with lower self-ratings of individual living conditions and of living conditions compared to others, voting patterns trend in the opposite direction: Amongst those without household services, better ward-level water coverage and toilet coverage is associated with a higher likelihood (not significant) of voting for the incumbent ANC.

Table 8: The effects of municipal-level service delivery coverage among those without household services

\begin{tabular}{|c|c|c|c|c|c|c|}
\hline & $\begin{array}{c}\text { Own Living } \\
\text { Model } 1\end{array}$ & $\begin{array}{c}\text { Own Living } \\
\text { Model } 2\end{array}$ & $\begin{array}{c}\text { Liv Comp Othrs } \\
\text { Model } 3\end{array}$ & $\begin{array}{c}\text { Liv Comp Othrs } \\
\text { Model } 4\end{array}$ & $\begin{array}{l}\text { ANC Vote } \\
\text { Model } 5\end{array}$ & $\begin{array}{l}\text { ANC Vote } \\
\text { Model } 6\end{array}$ \\
\hline home_water & $\begin{array}{l}-0.148 \\
(0.163)\end{array}$ & & $\begin{array}{l}-0.086 \\
(0.155)\end{array}$ & & $\begin{array}{c}0.213 \\
(0.215)\end{array}$ & \\
\hline all_flush & & $\begin{array}{c}-0.307^{* *} \\
(0.126)\end{array}$ & & $\begin{array}{c}-0.241^{*} \\
(0.124)\end{array}$ & & $\begin{array}{c}0.139 \\
(0.137)\end{array}$ \\
\hline whitefrac & $\begin{array}{c}0.475 \\
(0.719)\end{array}$ & $\begin{array}{c}1.375^{* *} \\
(0.681)\end{array}$ & $\begin{array}{c}0.290 \\
(0.536)\end{array}$ & $\begin{array}{l}0.976^{*} \\
(0.502)\end{array}$ & $\begin{array}{l}-0.671 \\
(0.700)\end{array}$ & $\begin{array}{l}-0.598 \\
(0.542)\end{array}$ \\
\hline urban & $\begin{array}{c}0.016 \\
(0.053)\end{array}$ & $\begin{array}{c}0.037 \\
(0.059)\end{array}$ & $\begin{array}{l}-0.027 \\
(0.047)\end{array}$ & $\begin{array}{l}-0.013 \\
(0.044)\end{array}$ & $\begin{array}{c}0.020 \\
(0.068)\end{array}$ & $\begin{array}{c}0.054 \\
(0.055)\end{array}$ \\
\hline female & $\begin{array}{c}0.005 \\
(0.025)\end{array}$ & $\begin{array}{c}0.032 \\
(0.031)\end{array}$ & $\begin{array}{c}0.024 \\
(0.022)\end{array}$ & $\begin{array}{c}0.043 \\
(0.027)\end{array}$ & $\begin{array}{c}0.028 \\
(0.033)\end{array}$ & $\begin{array}{c}0.035 \\
(0.041)\end{array}$ \\
\hline cashjob & $\begin{array}{c}0.075 \\
(0.049)\end{array}$ & $\begin{array}{c}0.117^{* *} \\
(0.051)\end{array}$ & $\begin{array}{l}0.069^{*} \\
(0.038)\end{array}$ & $\begin{array}{c}0.107^{* * * *} \\
(0.040)\end{array}$ & $\begin{array}{l}-0.039 \\
(0.067)\end{array}$ & $\begin{array}{l}-0.002 \\
(0.052)\end{array}$ \\
\hline educ & $\begin{array}{c}0.239^{* *} \\
(0.117)\end{array}$ & $\begin{array}{c}0.193 \\
(0.138)\end{array}$ & $\begin{array}{c}0.244^{* * *} \\
(0.090)\end{array}$ & $\begin{array}{c}0.326^{* * *} \\
(0.110)\end{array}$ & $\begin{array}{l}-0.029 \\
(0.163)\end{array}$ & $\begin{array}{l}-0.040 \\
(0.195)\end{array}$ \\
\hline age & $\begin{array}{l}-0.0005 \\
(0.001)\end{array}$ & $\begin{array}{l}0.0004 \\
(0.001)\end{array}$ & $\begin{array}{l}-0.001 \\
(0.001)\end{array}$ & $\begin{array}{l}0.0003 \\
(0.001)\end{array}$ & $\begin{array}{c}0.001 \\
(0.002)\end{array}$ & $\begin{array}{l}0.003^{*} \\
(0.002)\end{array}$ \\
\hline Constant & $\begin{array}{c}0.372^{* * *} \\
(0.085)\end{array}$ & $\begin{array}{c}0.383^{* * *} \\
(0.109)\end{array}$ & $\begin{array}{c}0.428^{* * *} \\
(0.063)\end{array}$ & $\begin{array}{c}0.395^{* * *} \\
(0.085)\end{array}$ & $\begin{array}{c}0.669^{* * *} \\
(0.115)\end{array}$ & $\begin{array}{c}0.569^{* * *} \\
(0.141)\end{array}$ \\
\hline $\mathrm{N}$ & 464 & 372 & 454 & 362 & 466 & 372 \\
\hline R-squared & 0.030 & 0.067 & 0.049 & 0.109 & 0.010 & 0.023 \\
\hline
\end{tabular}

In short, we find mixed evidence with respect to a relative deprivation mechanism driving citizens away from the ANC.

\subsubsection{Disappointment}

Another plausible correction to the core model would be an accounting of quality and satisfaction. The South African news media frequently reports on problems of service delivery beyond the provision of basic infrastructure, focusing on quality and flows. Citizens who receive services may find that the services are actually of poorer quality than anticipated. This may lead to disappointment and resentment - a resentment that is more intense than that expressed by those voters who did not receive any services. 
If disappointment explains our results, we should expect that, at the individual level, among those who receive services, those with the best quality services would be more likely to vote for the incumbent, and vice versa. In fact, the evidence available to us contradicts this prediction. We considered the subset of citizens who had indicated that their household had direct access to water service, and we analyzed their responses to the question of, "Over the past year, how often, if ever, have you or anyone in your family gone without enough clean water for home use?" We interpreted the responses to this question, for those who do have access to water facilities, as a good indicator of quality of water services. Although the vast majority (81 percent) reported no shortages, the remaining 19 percent reported various levels of shortages.

As we show in figure 6, those with more consistent water supply do rate the quality of government provision of water services and their own living conditions as being higher than those with shortages. Moreover, they provide higher ratings of their local councils and the president (though not with statistically significant provision). Yet we find essentially no impact of quality on the likelihood of supporting the ANC - the point estimate is even slightly negative, though not statistically distinguishable from zero.

\subsubsection{Perceived corruption}

Separate from the quality of services delivered, perhaps voters are disappointed with the process of delivery. The actual provision of government services entails closer contact with government officials and government contractors. During the process of service installation, citizens may observe, or at least perceive, that politicians and those working for government are privately enriching themselves, either by legal or illegal means. Indeed, author interviews conducted in June 2015 with local councilors in South Africa revealed that councilors themselves are often the ones who make decisions about which firms will receive the government contracts (known as "tenders") to deliver the services, and these decisions are frequently made based on personal connections and/or in exchange for private favors. When observed by constituents, this may lead to heightened dis- 
Figure 6: Household Water Service Quality and Citizen Attitudes and Intentions

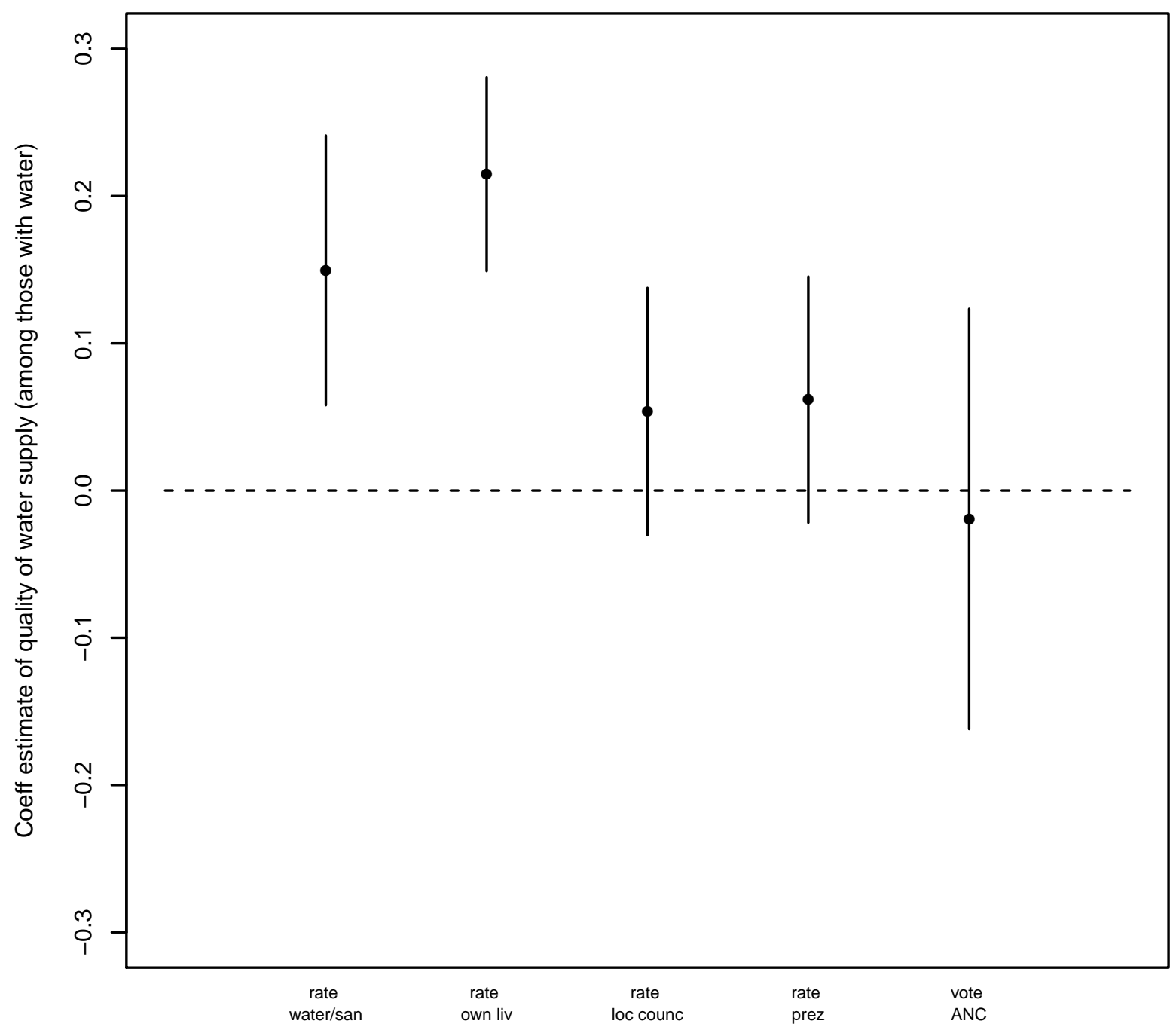

Note: Each panel presents coefficient estimates of consistency of water supply from OLS regressions, calculated with survey wave and municipality fixed effects. Sample restricted to Black respondents in ANC-controlled municipalities indicating a water tap inside the household or compound. Afrobarometer survey items listed on the X-axes are the outcome variables from separate regressions. Lines represent 95 percent confidence intervals. All standard errors are calculated by clustering data at the municipality-level. Individual-level controls include gender, age, educationlevel, dummy variables for home language (Xhosa or Zulu, with other as missing category), and a dummy variable for urban residence; and at the municipal-level, we control for log of population. Note that data about own water were only contained in rounds 4 and 5; and data about own toilets were only contained in wave 5 . 
content with the party in power. In the South African context, this explanation seems particularly plausible, and corruption is a central issue in the media and in political discourse.

Table 9: Service Provision and Perceptions of Corruption (AB Round 5 data, black respondents in ANC-controlled municipalities)

\begin{tabular}{|c|c|c|c|}
\hline & $\begin{array}{l}\text { ANC Vote } \\
\text { Model } 1\end{array}$ & $\begin{array}{c}\text { Perceive Corruption } \\
\text { Model } 2\end{array}$ & $\begin{array}{c}\text { Perceive Corruption } \\
\text { Model } 3\end{array}$ \\
\hline corrupt & $\begin{array}{l}-0.150^{* *} \\
(0.061)\end{array}$ & & \\
\hline ownwater & & $\begin{array}{c}0.056^{* * *} \\
(0.016)\end{array}$ & \\
\hline owntoilet & & & $\begin{array}{l}0.111^{* * *} \\
(0.036)\end{array}$ \\
\hline urban & $\begin{array}{l}-0.012 \\
(0.035)\end{array}$ & $\begin{array}{c}0.003 \\
(0.015)\end{array}$ & $\begin{array}{c}0.001 \\
(0.014)\end{array}$ \\
\hline female & $\begin{array}{l}-0.010 \\
(0.022)\end{array}$ & $\begin{array}{l}-0.019^{*} \\
(0.011)\end{array}$ & $\begin{array}{l}-0.016 \\
(0.011)\end{array}$ \\
\hline cashjob & $\begin{array}{c}-0.0002 \\
(0.030)\end{array}$ & $\begin{array}{l}-0.016 \\
(0.027)\end{array}$ & $\begin{array}{l}-0.013 \\
(0.027)\end{array}$ \\
\hline educ & $\begin{array}{c}-0.254^{* * *} \\
(0.091)\end{array}$ & $\begin{array}{l}-0.040 \\
(0.056)\end{array}$ & $\begin{array}{l}-0.055 \\
(0.056)\end{array}$ \\
\hline age & $\begin{array}{l}0.002^{*} \\
(0.001)\end{array}$ & $\begin{array}{l}-0.0004 \\
(0.0005)\end{array}$ & $\begin{array}{l}-0.0004 \\
(0.0005)\end{array}$ \\
\hline Constant & $\begin{array}{c}0.857^{* * *} \\
(0.076)\end{array}$ & $\begin{array}{c}0.552^{* * *} \\
(0.039)\end{array}$ & $\begin{array}{l}0.514^{* * *} \\
(0.042)\end{array}$ \\
\hline $\mathrm{N}$ & 1279 & 1279 & 1277 \\
\hline R-squared & 0.021 & 0.011 & 0.023 \\
\hline
\end{tabular}

In fact, we find some evidence consistent with this mechanism. Again, when considering black voters in ANC-controlled localities, table 9 shows that those who report perceiving corruption are substantially less likely to vote for the ANC, and secondly that those with access to water and toilets within their household tend to perceive higher rates of corruption than those without. Admittedly, this is only preliminary evidence of the plausibility of this mechanism - we cannot, from these analyses, demonstrate that these correlations are linked in a causal manner. But when combined with investigator-conducted interviews, these findings are highly suggestive. 


\subsection{STRATEGIES AND UPDATING}

Whereas the mechanisms outlined above highlight the role of alternative citizen reactions to the actual delivery of services, another possibility is that democratic accountability is really mediated through the strategic behavior of citizens, voters, and parties in a dynamic democratic environment. Again, while the standard view of electoral accoutability focuses on reward and punishment by voters based on the record of incumbents (retrospective voting), it may be the case that citizens are looking to the future, or that opposition parties are most active in areas where service delivery is strongest.

\subsubsection{Voter strategies and changing expectations}

Perhaps the patterns we observe are a function of the fact that voters view the ANC as a party whose primary programmatic platform is to provide basic services? If that is the case, those who have received services may feel that they no longer need the ANC to deliver. In turn, such individuals might become less likely to vote for the ANC. On the flip-side, those without services may "double-down" and vote for the ANC in the hopes that they too might receive services in the future.

If this mechanism were at work, we should find that those who have received services express different preferences for government action. In particular, they should be less likely to demand basic service provision, and in turn, those preferences ought to be good predictors of support for the incumbent. We find exactly this: those who have water access are less likely to list water as a government priority. Among those Black citizens in ANC-controlled areas without any home water service, 10.8 percent said that water should be a top priority for government, whereas just 5.2 percent of those with home water said this should be a top priority. In turn, we also find that demand for water services is a good predictor of ANC vote intentions (reported in the 
Appendix) ${ }^{21}$ We take this to be suggestive evidence that this mechanism may be at work. More specifically, the results imply that voters are not using information about service provision to weed out "good" politicians or parties from "bad." Rather, they are using this information to calibrate their expectations of the party's programmatic platforms. For voters who already benefit from basic service provision, they no longer value this core program as a party platform, and will not be motivated to vote for it.

\section{CONCLUSION}

Our motivation for this study was to investigate the recent expansion of infrastructural services in an important democratic region. We test a core assumption underlying most theories of electoral accountability. Specifically, a powerful normative justification for democratic government is that voters can hold politicians responsible for service delivery. And by voting for the incumbent where service delivery has occurred, this should send a clear feedback signal to governments, and help to sort the quality of elected leaders. Our analysis demonstrates that reality deviates substantially from such straightforward predictions: In South Africa, voters who receive services, whether in incumbent- or opposition-controlled localities, are generally less likely to support the dominant ANC party. This basic pattern appears to hold in the other three regional democracies, Botswana, Lesotho, and Namibia.

The broader normative implication of these findings - whether they are "good" or "bad" news for the welfare-enhancing effects of democratic governance - depend on the mechanism that explains this pattern, and how political parties react to evidence of declining incumbent support in the wake of service expansion. One dismal prediction is that parties in power could infer that service delivery is counter-productive for returning to power. If incumbents are punished because improvements lead to feelings of "relative deprivation," they might choose to keep everyone deprived. But we

\footnotetext{
${ }^{21}$ Relatedly, Mattes 2015 finds that members of South Africa's black middle class are more likely to want "higher order" goods rather than basic survival goods and are less likely to support the ANC than are other black South Africans.
} 
find only mixed support for that account.

On the other hand, if the quality of service provision in opposition-controlled localities is a key driver of even national election vote choices, that may bode well for competitive democracy and provide some challenge to the notion of an "incumbency advantage." Within incumbent-controlled localities, if the mechanism is "changing expectations," it could be the case that incumbent parties will work even harder to meet those demands in a timely manner in order to maintain and to build electoral support. And if corruption is attenuating the effect of electoral gains from service delivery, perhaps parties in power will work harder to control such behavior. What is clear is that voters are responsive to changes in service delivery, but we find that the ways in which they respond are more nuanced than previously understood. While loyalties for revolutionary/liberation parties, and racial/ethnic identities are surely still important predictors of voting behavior, our findings contribute to an emerging literature highlighting that African voters are also driven by programmatic concerns. Additional research will be needed to more definitively address the questions of why voters have behaved in the manner we find, and with what consequences for government action.

Finally, it is worth asking whether the Southern African context is exceptional, and whether we should expect similar or different outcomes in other countries? Other young democracies across the world share many of the region's characteristics: Ruled by dominant parties, profoundly unequal, and racially- or ethnically-polarized. Whether or not citizens in other countries react to the delivery of services in the same manner is a pressing question that should be addressed. 


\section{REFERENCES}

Ashworth, Scott. 2012. "Electoral Accountability: Recent Theoretical and Empirical Work." Annual Review of Political Science 15:183-201.

Besley, Timothy and Robin Burgess. 2001. "Political agency, government responsiveness and the role of the media." European Economic Review 45(4ё̈6):629-640.

URL: http://www.sciencedirect.com/science/article/pii/S0014292101001337

Booysen, S. 2007. "With the ballot and the brick: The politics of attaining service delivery." Progress in Development Studies 7(February 2004):21-32.

Bratton, Michael and Robert Mattes. 2003. "Support for economic reform? Popular attitudes in Southern Africa." World Development 31(2):303-323.

Brown, David S. 1999. "Reading, Writing, and Regime Type: Democracy's Impact on Primary School Enrollment." Political Research Quarterly 52(4):681-707.

URL: http://www.jstor.org/stable/449181

Bruns, Barbara, Deon Filmer and Harry Anthony Patrinos. 2011. Making schools work : new evidence on accountability reforms. Washington DC: World Bank Publications.

Dinkelman, Taryn. 2011. "The effects of rural electrification on employment: New evidence from South Africa." The American Economic Review 101:3078-3108.

Downs, Anthony. 1957. "An economic theory of democracy." Journal of Political Economy 65(2).

Fearon, James D. 1999. "Electoral accountability and the control of politicians: selecting good types versus sanctioning poor performance." Democracy, accountability, and representation 55:61.

Ferree, K E. 2006. "Explaining South Africa's Racial Census." Journal of Politics 68(4):803-815.

Gerring, John, Strom C Thacker and Rodrigo Alfaro. 2011. "Democracy and Human Development." Journal of Politics 74(1):1-17.

URL: http://dx.doi.org/10.1017/S0022381611001113

Golden, Miriam and Brian Min. 2013. "Distributive politics around the world." Annual Review of Political Science 16:73-99.

Gottlieb, Jessica. 2015. "Greater Expectations: A Field Experiment to Improve Accountability in Mali." American Journal of Political Science 00:1-15.

URL: http://dx.doi.org/10.1111/ajps.12186

Haggard, Stephan and Robert R Kaufman. 2008. Development, democracy, and welfare states : Latin America, East Asia, and Eastern Europe. Princeton, N.J.: Princeton University Press.

Hainmueller, Jens, Jonathan Mummolo and Yiqing Xu. 2016. "How Much Should We Trust Estimates from Multiplicative Interaction Models? Simple Tools to Improve Empirical Practice." SSRN Working Paper. 
Harding, Robin. 2015. "Attribution and Accountability: Voting for Roads in Ghana." World Politics .

Harding, Robin and David Stasavage. 2013. "What Democracy Does (and Doesn't Do) for Basic Services: School Fees, School Inputs, and African Elections." The Journal of Politics 76(01):229245.

URL: http://journals.cambridge.org/abstract_S0022381613001254

Ho, D E, K Imai, G King and E A Stuart. 2007. "Matching as nonparametric preprocessing for reducing model dependence in parametric causal inference." Political Analysis 15(3):199-236.

Kroth, Verena. 2014. Essays in political economy: elections, public finance and service delivery in South Africa PhD thesis The London School of Economics and Political Science (LSE).

Kroth, Verena, Valentino Larcinese and Joachim Wehner. 2015. "A Better Life For All? Democratization and Electrification in Post-Apartheid South Africa.".

Lake, David A and Matthew A Baum. 2001. "The invisible hand of democracy." Comparative Political Studies 34(6):587-621.

URL: http://cps.sagepub.com/cgi/content/abstract/34/6/587

Lieberman, Evan S., Daniel N. Posner and Lily L. Tsai. 2014. "Does Information Lead to More Active Citizenship? Evidence from an Education Intervention in Rural Kenya." World Development 60:69-83.

URL: http://www.sciencedirect.com/science/article/pii/S0305750X14000801

Lipset, Seymour Martin. 1959. "Some social requisites of democracy: Economic development and political legitimacy." American political science review 53(01):69-105.

Mani, Anandi and Sharun Mukand. 2007. "Democracy, visibility and public good provision." Journal of Development Economics 83(2):506-529.

URL: http://www.sciencedirect.com/science/article/pii/S0304387806000642

Mattes, R and J Piombo. 2001. "Opposition Parties and the Voters in South Africa's General Election of 1999." Democratization 8(3):101-128.

URL: http://dx.doi.org/10.1080/r14000211

Mattes, Robert. 2015. "South Africa's emerging black middle class: A harbinger of political change?" Journal of International Development 27(5):665-692.

Mattes, Robert B. 1995. The election book: Judgement and choice in South Africa's 1994 election. IDASA, Public Information Centre.

Pande, Rohini. 2011. "Can informed voters enforce better governance? Experiments in low-income democracies." Annu. Rev. Econ. 3(1):215-237.

Posner, Daniel N and David J Simon. 2002. "Economic Conditions and Incumbent Support in Africa's New Democracies Evidence from Zambia." Comparative Political Studies 35(3):313-336. 
Przeworski, Adam, Michael E Alvarez, Jose Antonio Cheibub and Fernando Limongi. 2000. Democracy and Development : Political Institutions and Material Well-Being in the World, 1950-1990. Cambridge: Cambridge University Press.

Ravallion, Martin and Michael Lokshin. 2010. "Who cares about relative deprivation?" Journal of Economic Behavior and Organization 73:171-185.

Ross, Michael. 2006. "Is democracy good for the poor?" American Journal of Political Science 50(4):860-874.

Sandefur, Justin and Amanda Glassman. 2013. "The Political Economy of Bad Data: Evidence from African Survey \& Administrative Statistics." The Journal of Development Studies 51(2):116-132.

URL: http://www1.wider.unu.edu/inclusivegrowth/sites/default/files/IGA/Sandefur.pdf

Stasavage, David. 2005a. "Democracy and Education Spending in Africa." American Journal of Political Science 49(2):343-358.

URL: http://www.jstor.org/stable/3647681

Stasavage, David. 2005b. "The Role of Democracy in Uganda's Move to Universal Primary Education." The Journal of Modern African Studies 43(1):53-73.

URL: http://www.jstor.org/stable/3876259

Stewart, Quincy Thomas. 2006. "Reinvigorating relative deprivation: A new measure for a classic concept." Social Science Research 35:779-802.

Svolik, Milan W. 2013. "Learning to love democracy: Electoral accountability and the success of democracy." American Journal of Political Science 57:685-702.

Thachil, Tariq. 2014. "Elite Parties and Poor Voters: Theory and Evidence from India." American Political Science Review 108(02):454-477.

URL: http://www.journals.cambridge.org/abstract_S0003055414000069

Weghorst, Keith R and Staffan I Lindberg. 2013. "What Drives the Swing Voter in Africa?" American Journal of Political Science 57(3):717-734.

URL: 10.1111/ajps.12022 http://libproxy.mit.edu/login?url=http://search.ebscohost.com/login.aspx?direct live

World Bank. 2003. "World Development Report 2004 Making Services Work for Poor People.".

URL: http://elibrary.worldbank.org/content/book/9780821354681

World Bank. 2011. Accountability in public services in South Africa. Technical report World Bank Washington D.C.: . 